This article has been scanned by iThenticat No plagiarism detected

Volume 3, Issue 4, August 2021

p. 22-38

\title{
THE ROLE OF THE TEACHER IN THE DISTANCE LEARNING PROCESS IN LIGHT OF THE CORONA PANDEMIC AND ITS RELATIONSHIP TO TAKING INTO ACCOUNT INDIVIDUAL DIFFERENCES AMONG STUDENTS IN ARAB PRIMARY SCHOOLS
}

http://dx.doi.org/10.47832/2757-5403.4-3.3

\section{Nadia GHALIA ${ }^{1}$ \& Sawsan KARA²}

\begin{abstract}
:
The study aimed to identify the role of the teacher in the distance learning process in schools within the Green Line from the perspectives of teachers and school principals in them, as well as to reveal the level of consideration of individual differences and the statement of the relationship between them. The survey descriptive approach was used, the study sample included teachers and principals in primary schools, who numbered (330) teachers and principals. The primary school was significant, and the results showed that there were no statistically significant differences attributed to the study variables about the teacher's role in the distance learning process in light of the Corona pandemic and its relationship to taking into account individual differences among students in Arab primary schools.
\end{abstract}

Key words: Distance Learning, Individual Differences, Primary Schools.

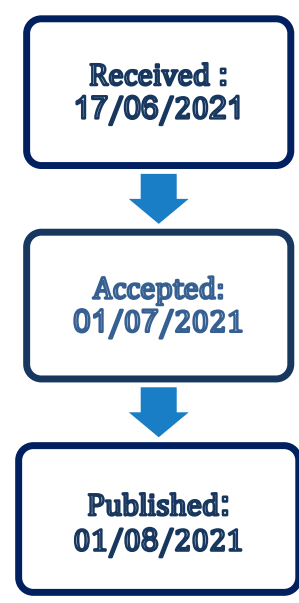

\footnotetext{
${ }^{1}$ Prof. Dr. , International Studies Department, Israel, nadihgali@gmail.com, https://orcid.org/0000-0002-90395717

${ }^{2}$ Prof. Dr. , Paris College of International Education (PCIE), srael, y.kara@bezeqint.net, https://orcid.org/0000$\underline{0003-4575-6146}$
}

Copyright (C) Published by IJHER Journal, www.ijherjournal.com Rimar Academy, Fatih, Istanbul, 34093 Turkey

All rights reserved 


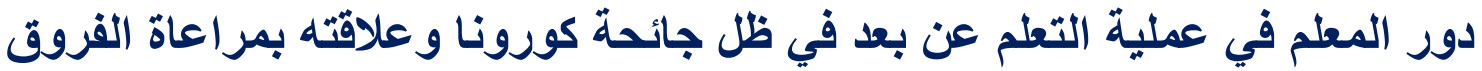 الفردية لاى الطلبة في المدارس العربية الابتدائية
}

\author{
ناديا غالية \\ سوسن يوسف قراليا
}

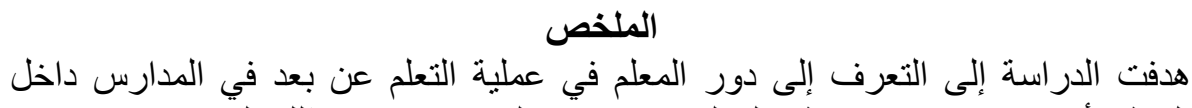

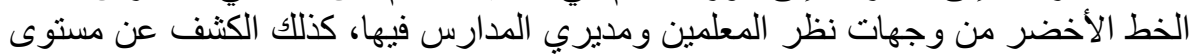

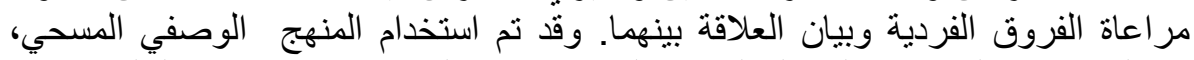

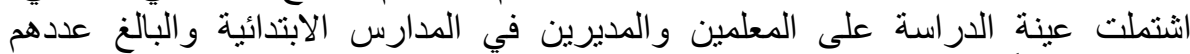

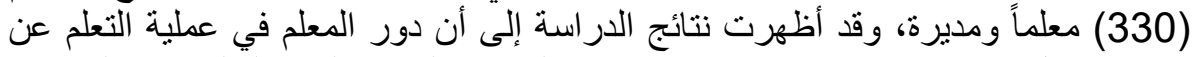

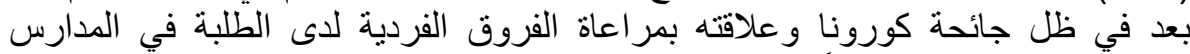

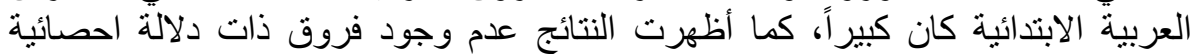

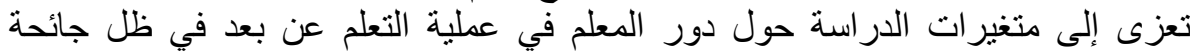
كورونا وعلاقته بمر اعاة الفروق الفردية الفية لدى الطلبة في المدارس العربية الابتدائية. الكلمات المفتاحية: التعلم عند بعد، الفروق الفردية، الفية المدارس الابتدائية.
\end{abstract}

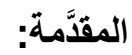

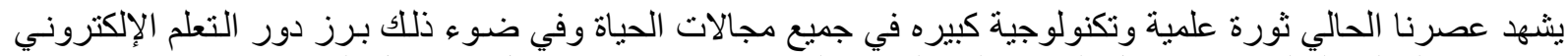

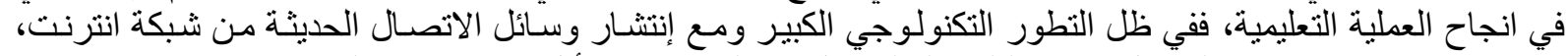

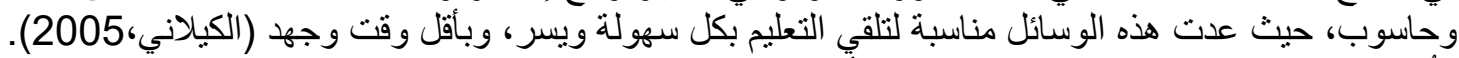

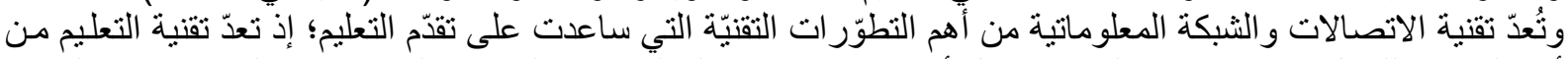

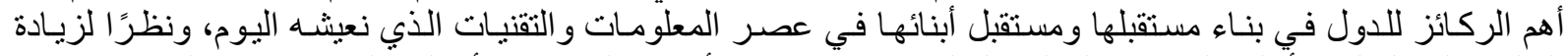

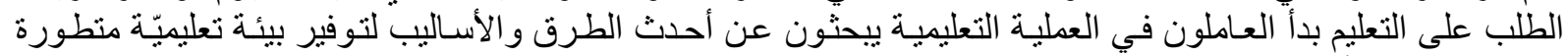

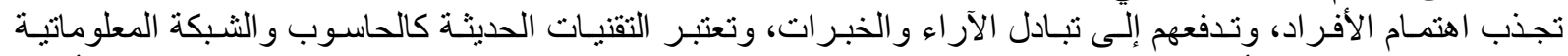

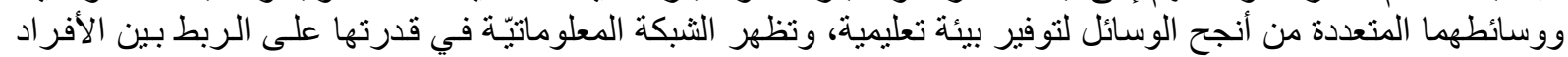

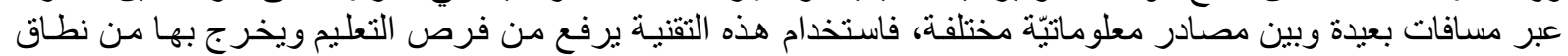

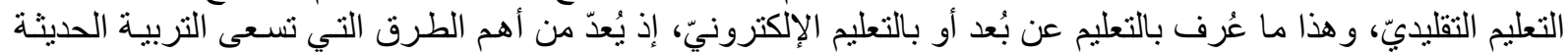

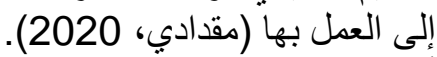

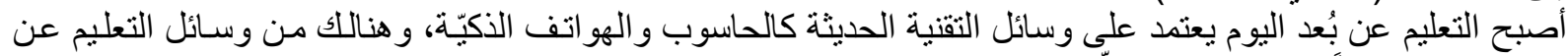

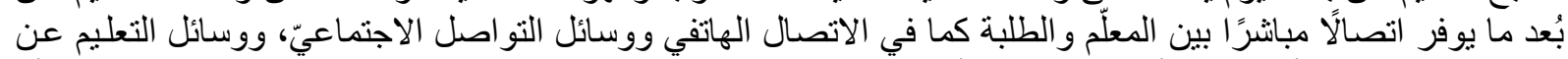

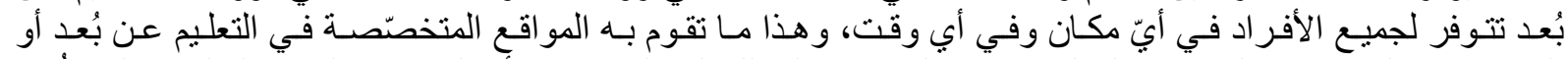

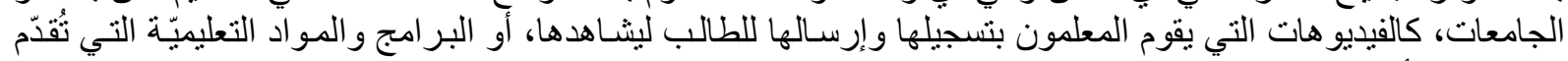

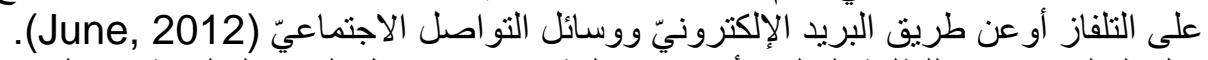

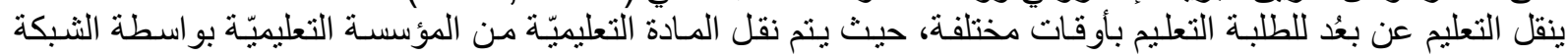

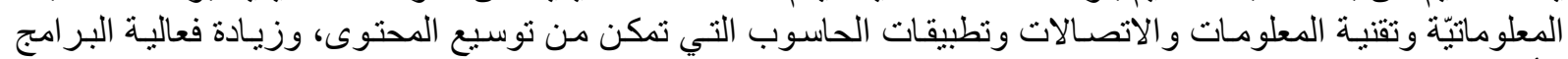

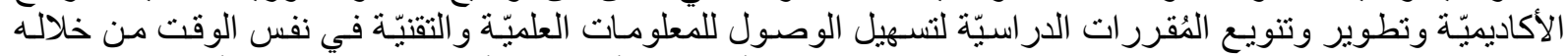

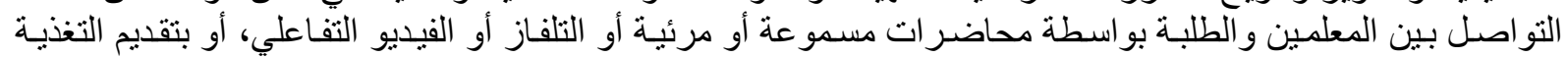

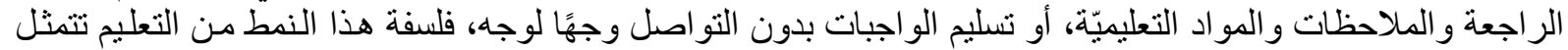

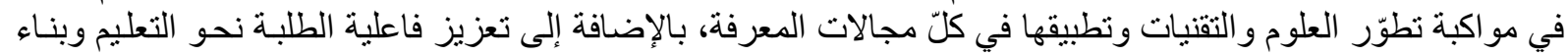

مستقبلهم (الزبون، 2020).

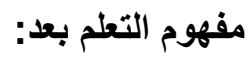

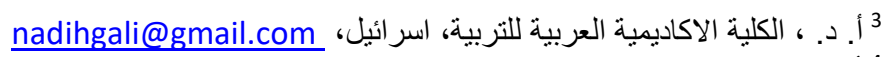

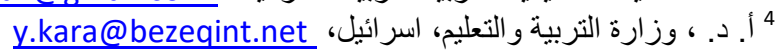




\section{THE ROLE OF THE TEACHER IN THE DISTANCE LEARNING PROCESS IN \\ LIGHT OF THE CORONA PANDEMIC AND ITS RELATIONSHIP TO TAKING \\ INTO ACCOUNT INDIVIDUAL DIFFERENCES AMONG STUDENTS IN ARAB \\ PRIMARY SCHOOLS}

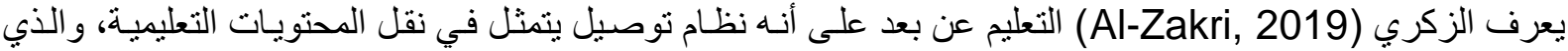

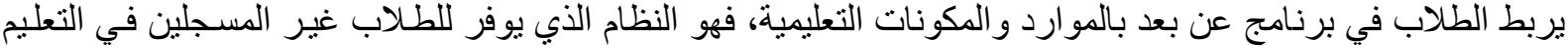

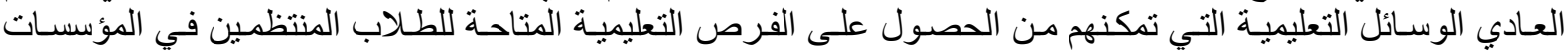
التعليمية تقليديا.

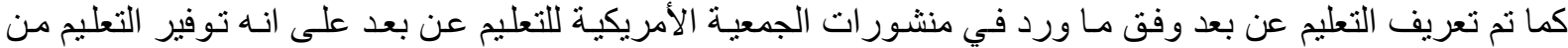

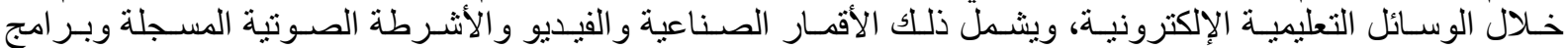

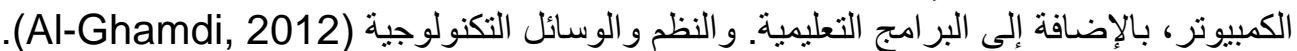

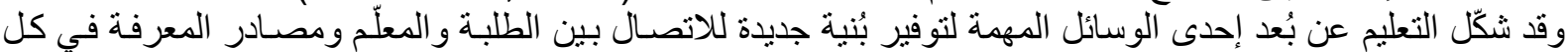

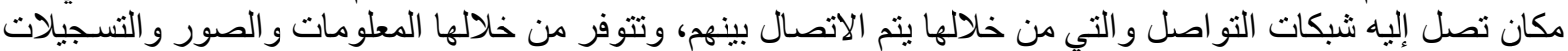

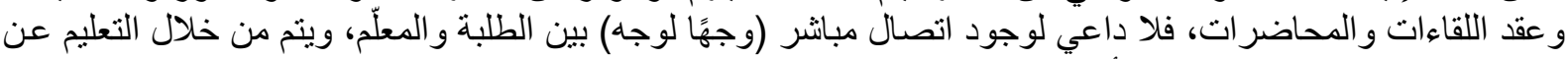

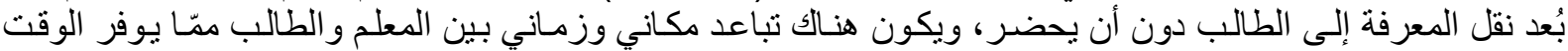

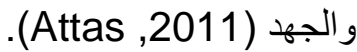
إن تطلع مؤسسات التعليم لاستبدال التعليم التقليدي بنمط التعليم عن بُعد، (عامر، 2014) نـاتج عن الأهمية الكبيرة التي

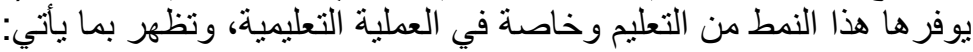

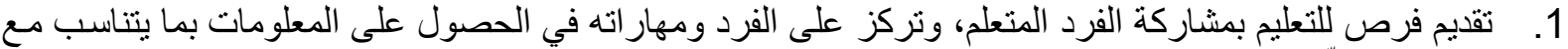
نظريات التعلّم الحديثة.

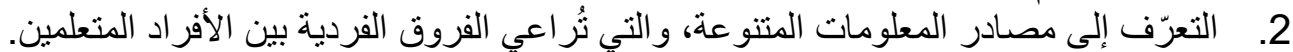

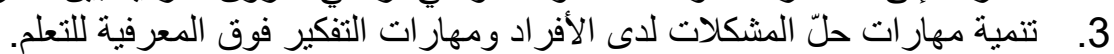

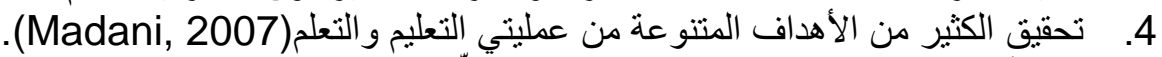

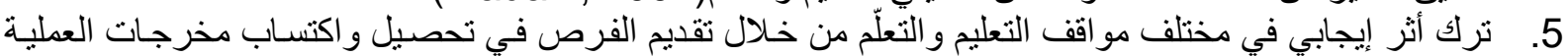
التعليمية

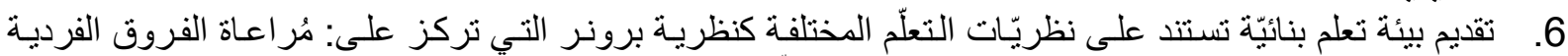

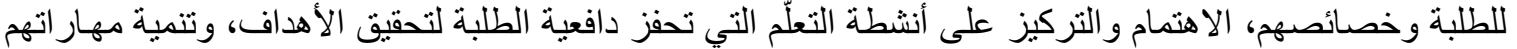

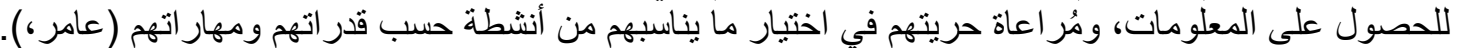

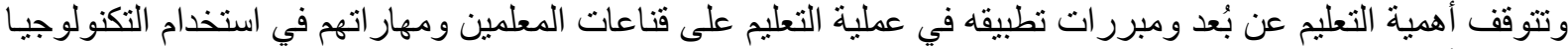

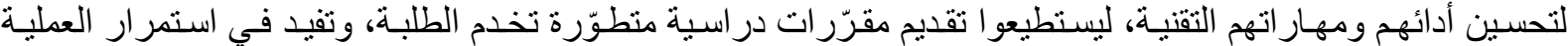

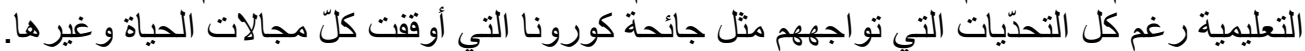

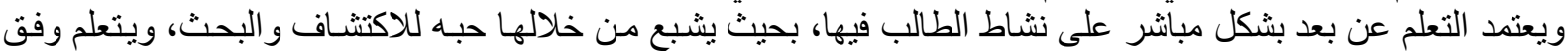

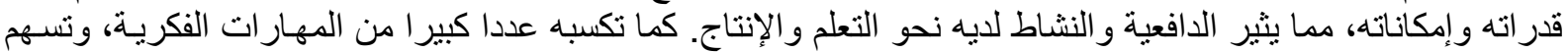

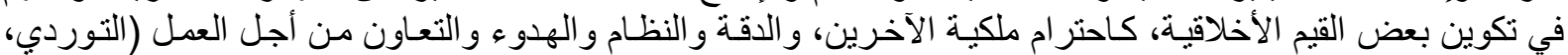

2004

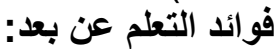

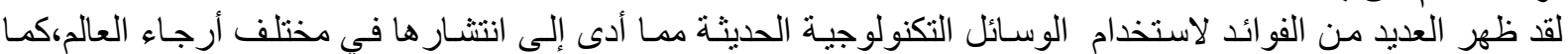

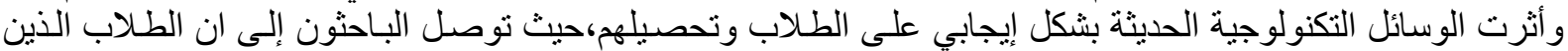

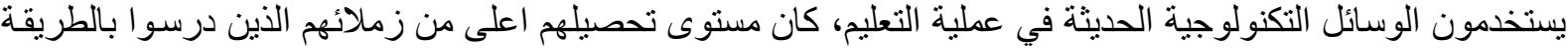

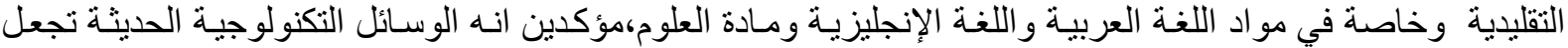

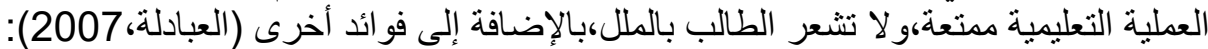

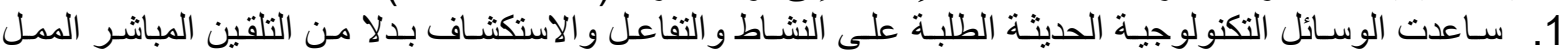

2. ساعدت الوسائل التكنولوجية في لفت انتباه الطلاب وقللت بنفس الوقت من الطلاب الذين يشرد تفكير هم و انتباههر

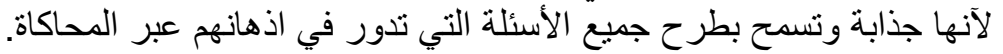

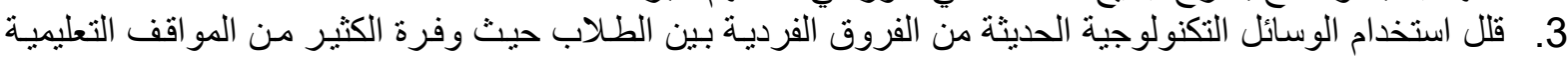

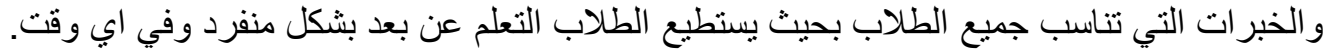

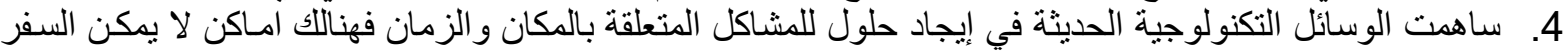

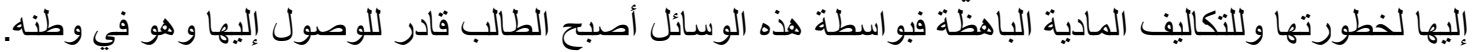


5. ساهمت الوسائل التكنولوجية الحديثة في حل مشكلة النقص في المعلمين الأكفاء فبو اسطة هذه الوسائل اصبح الطالب البكاب

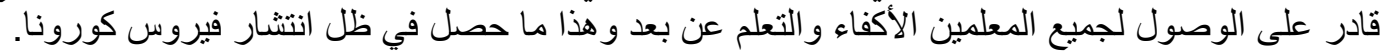

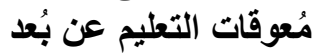
هناك العديد من المُعوقات ونُو التحديات التي تحدّ من انتشار التعليم عن بُعد و الاستفادة منه في مجال التربية و التعليم ومنها:

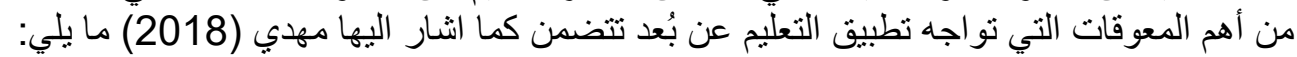

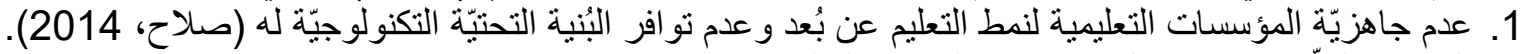

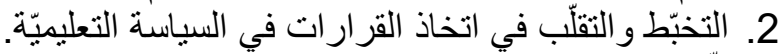

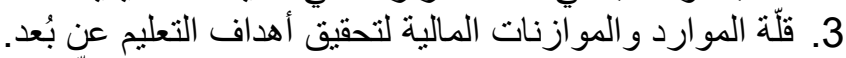

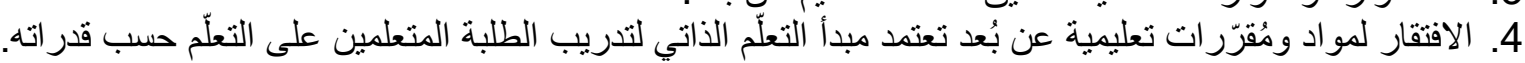

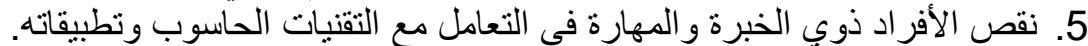
6. صعوبة التحوّل من نمط التعليم التقليديّ إلى نمط التعليم الحديث، وديث ومقاومة هذا النمط من التعليم وقلة التفاعل و الجدية في التعامل معده. 7. قلّة مستوى و وعي المجتمع بهذا النمط من التعليم، إذ يجب أن يكون هناك قناعة ونقافة اجتماعيّة بفاعلية نمط التعليم عن

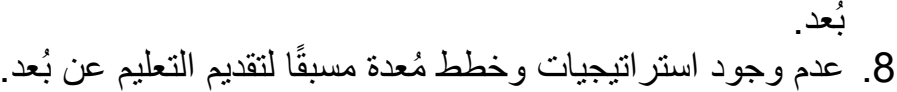

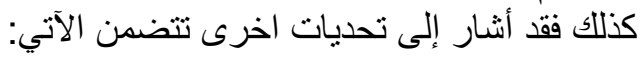

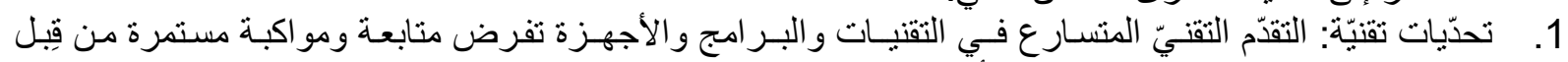

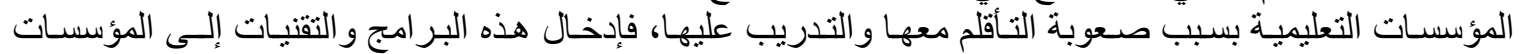

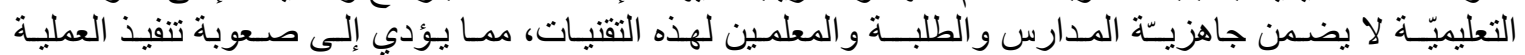
التعليمية ومهامها.

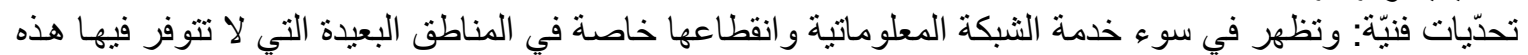

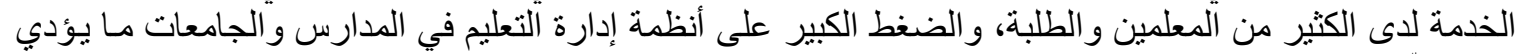

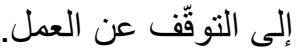

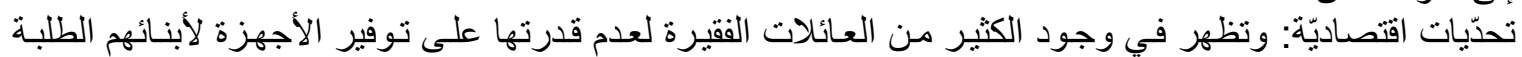

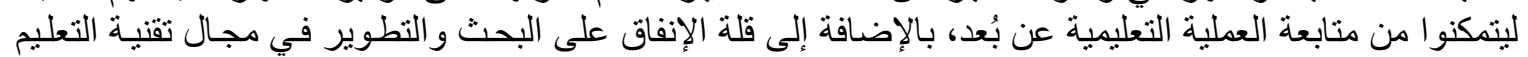

(Musingafi and Zebron,.(2015)

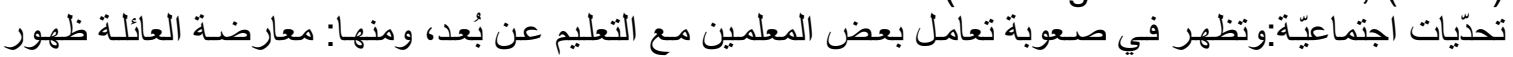

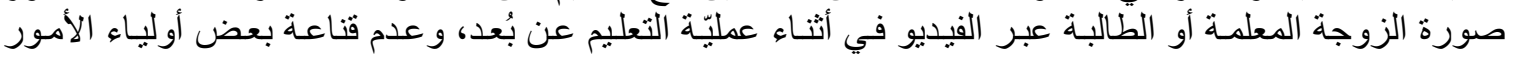

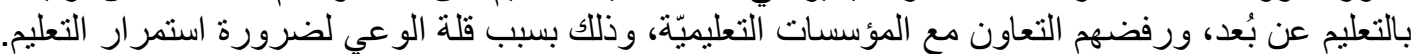

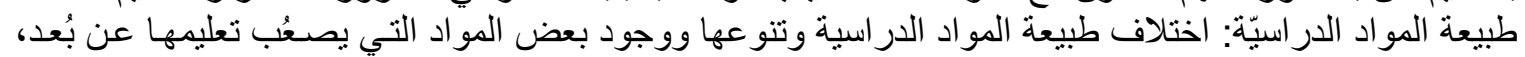

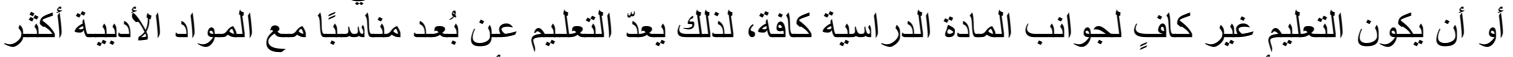

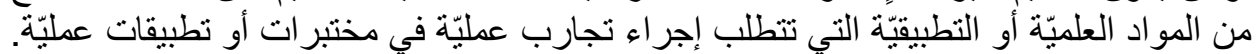

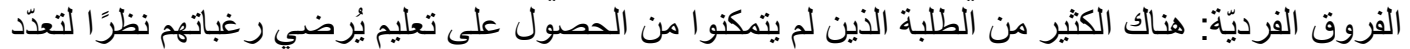

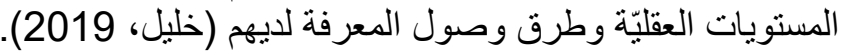

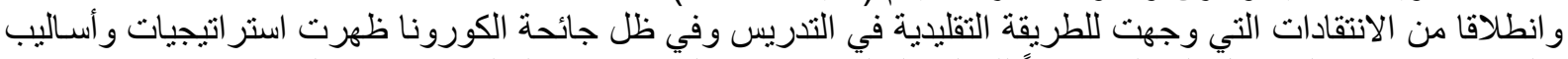

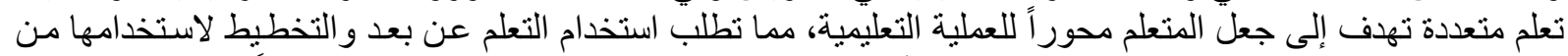

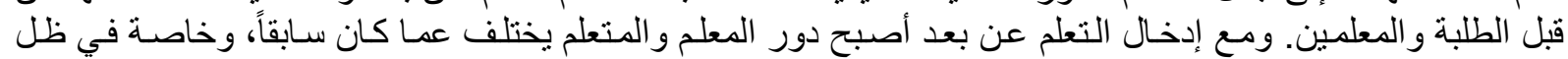
منظومة تكنولوجيا المعلومات.

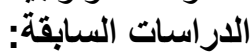

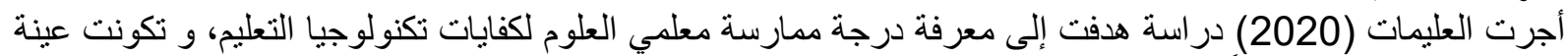

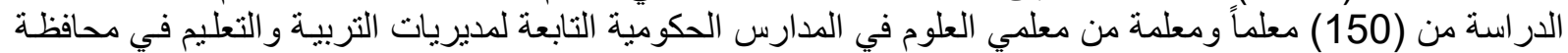

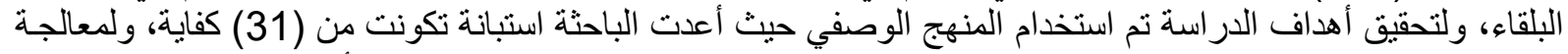

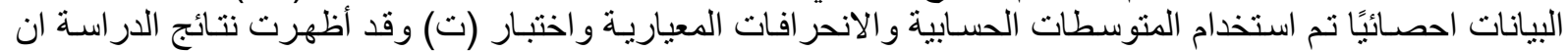

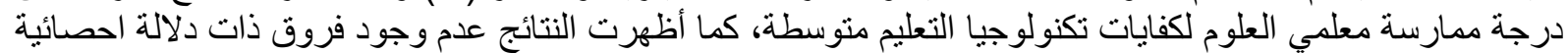

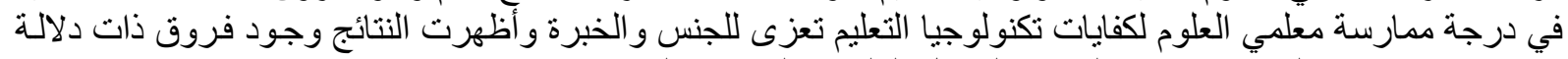

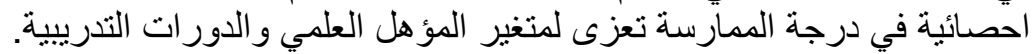

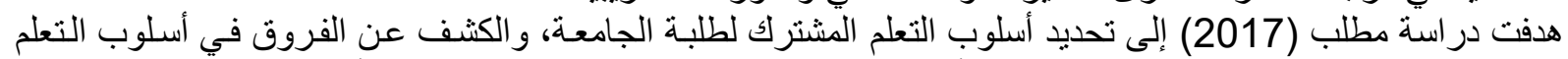

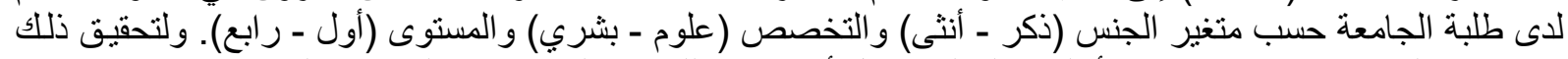

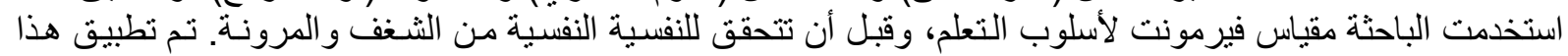




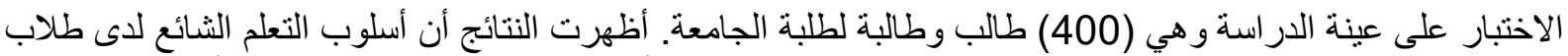

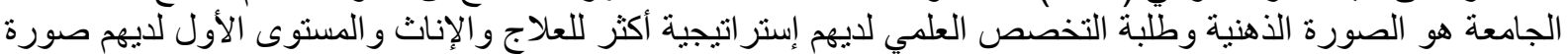

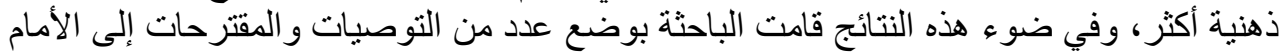

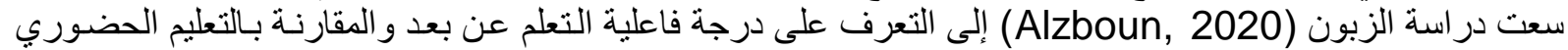

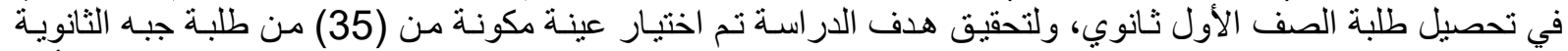

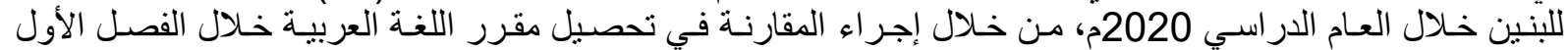

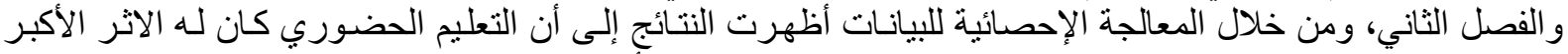

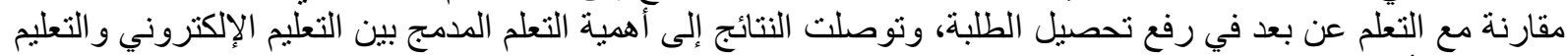

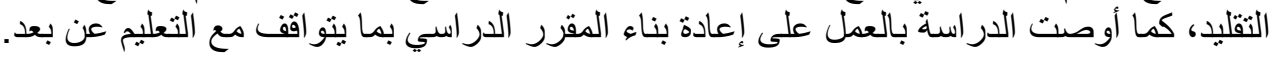

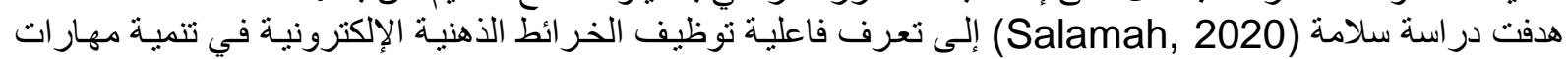

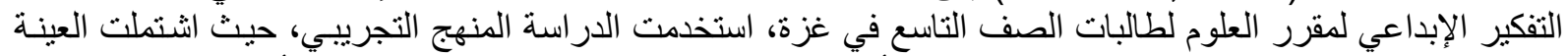

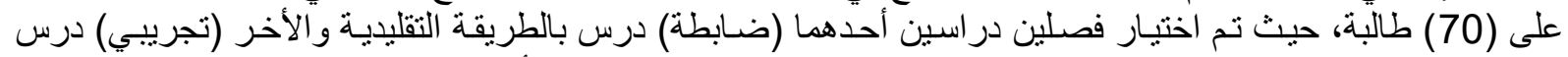

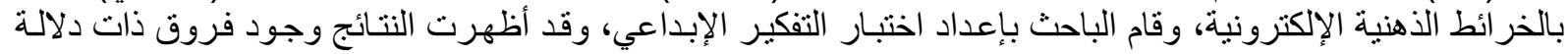

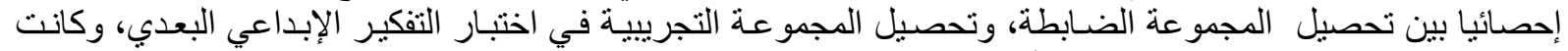

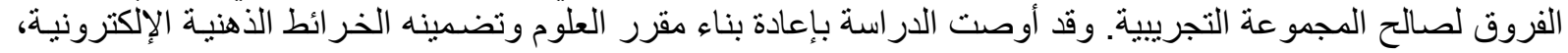
وتدريب المعلمين على طريقة تضمينها العمليات التدريسية.

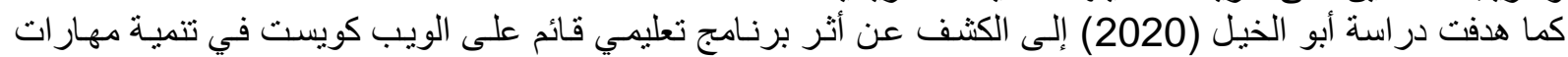

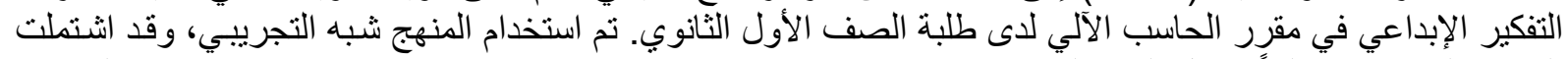

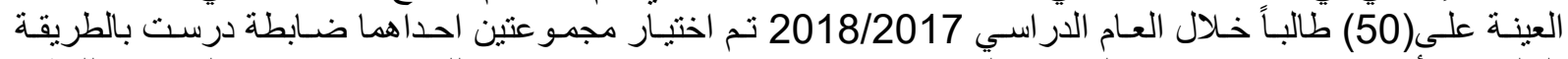

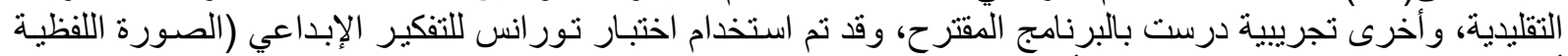

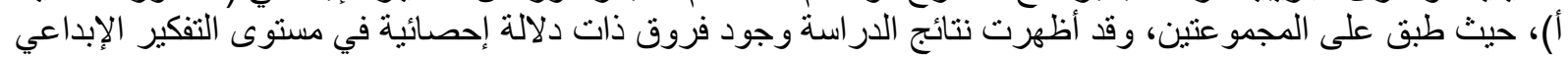

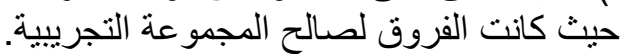

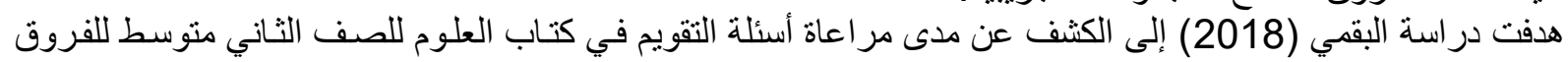

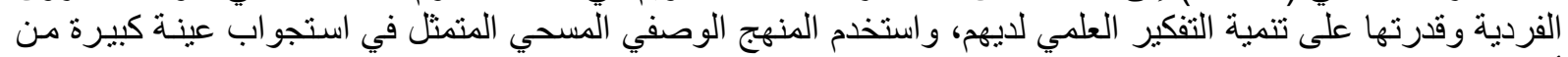

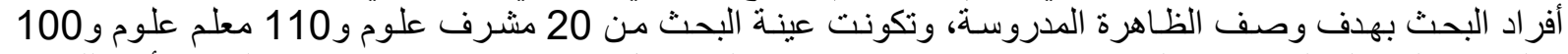

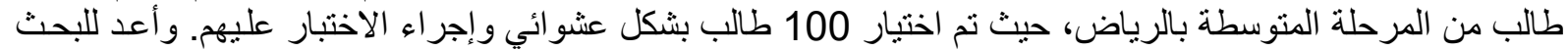

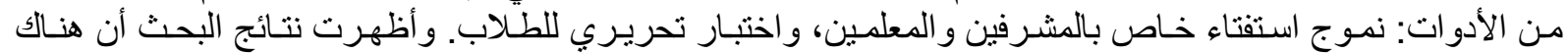

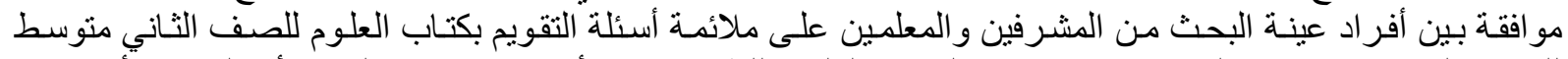

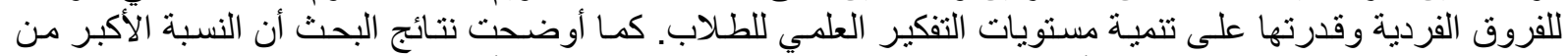

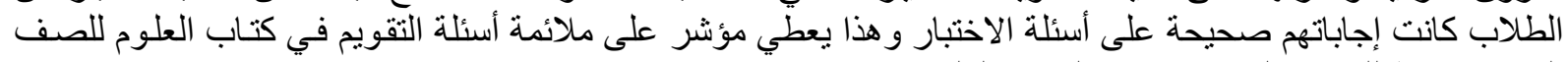
الثاني متوسط للفروق الفابت الفردية وتنمية التقكير العلمي.

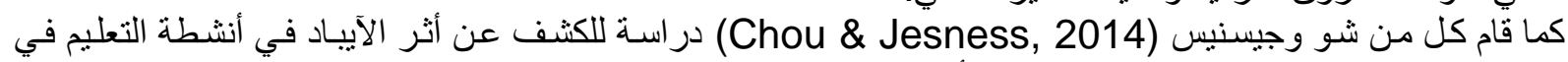

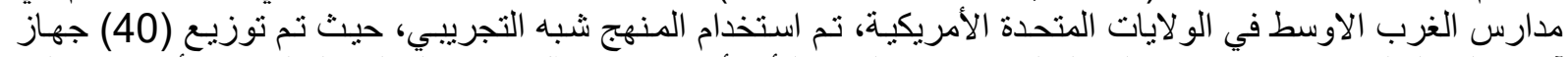

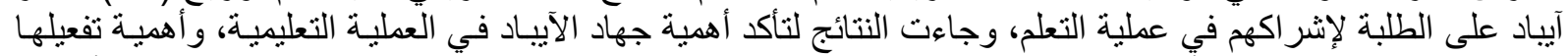

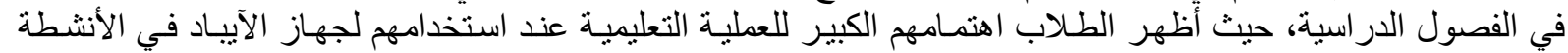
التعليمبة

هدفت دراسة جون (June, 2012) إلى مقارنة المعرفة المكتسبة بين نمطين من أنماط التعلم، التعلم الإلكتروني و التعليم

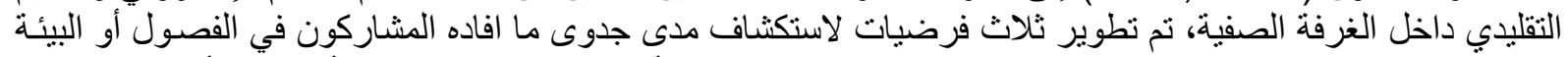

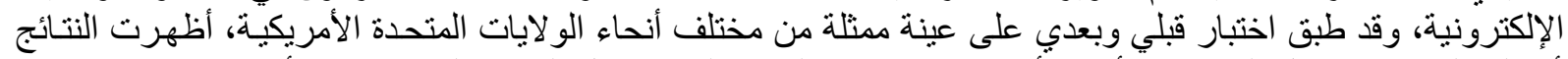

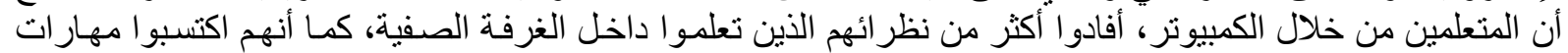
أكثر من غبر هم.

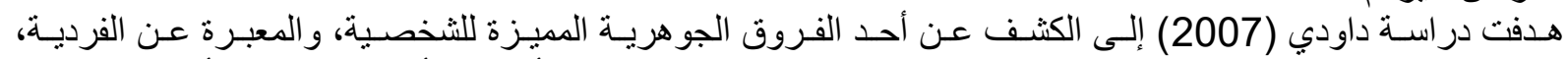

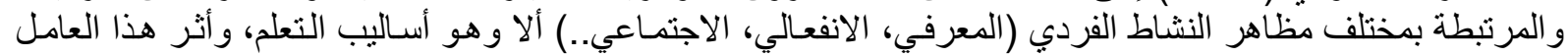

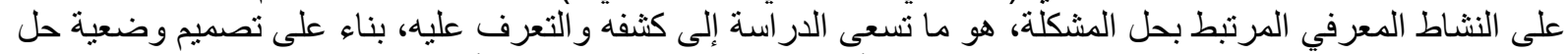

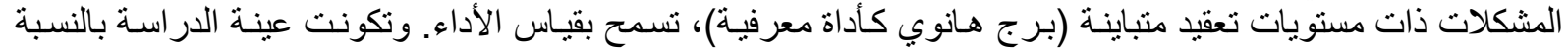




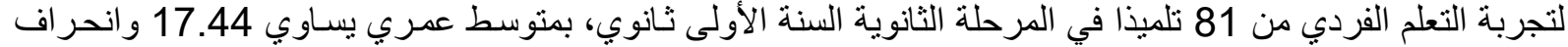

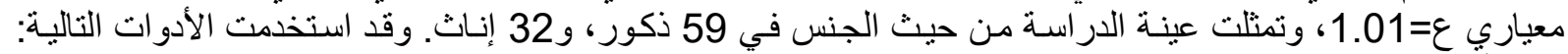

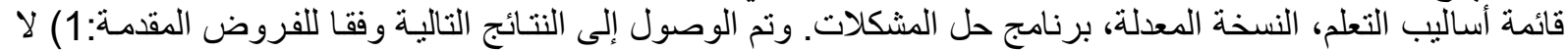

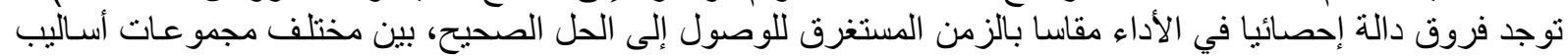

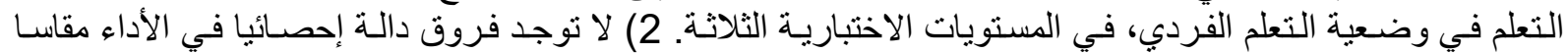

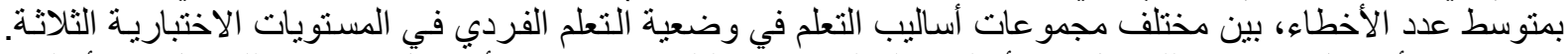

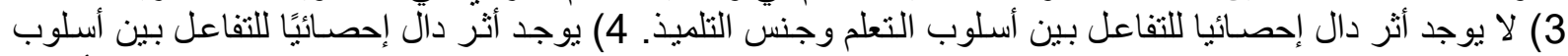

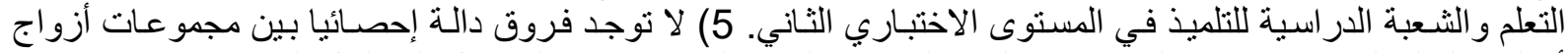

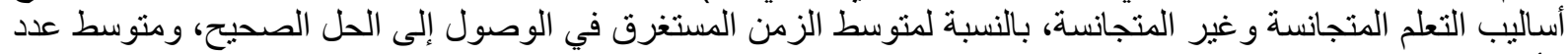
الأخطاء في المستوى الاختباري الثناني.

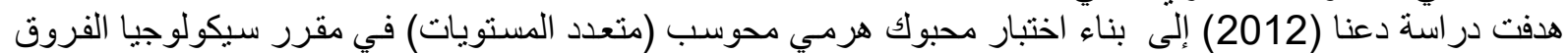

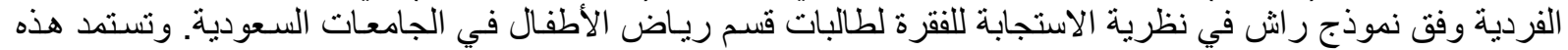

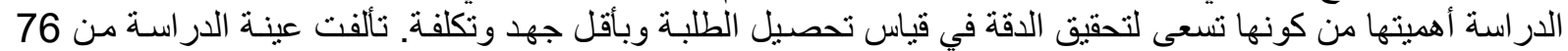

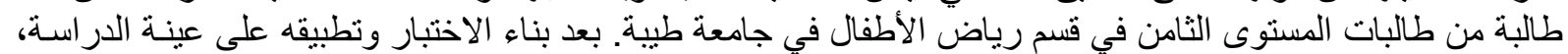

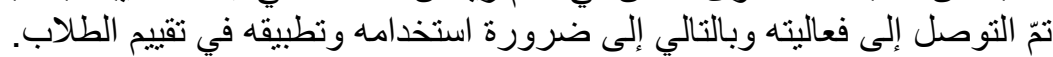

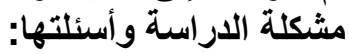

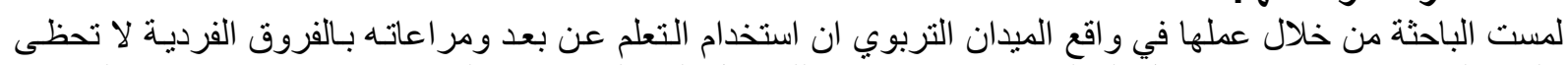

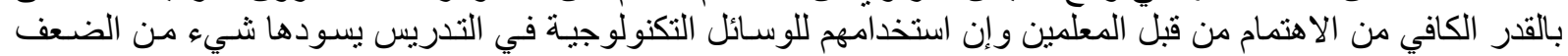

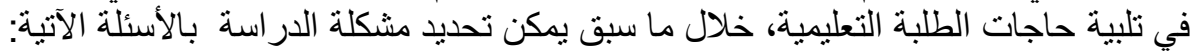

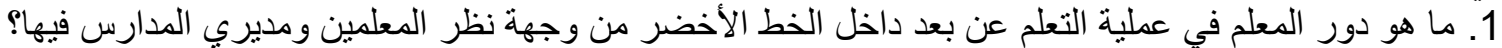

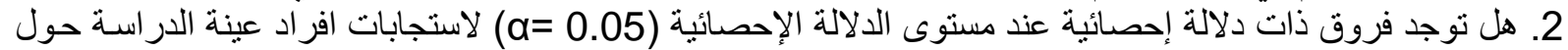

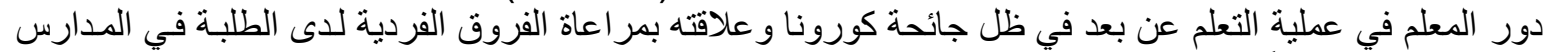

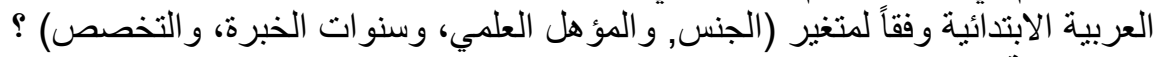

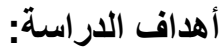

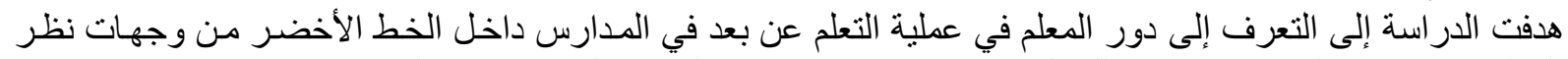

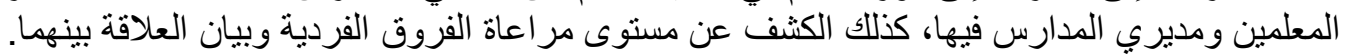

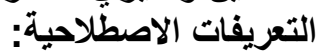

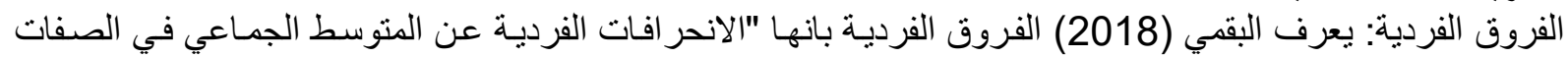

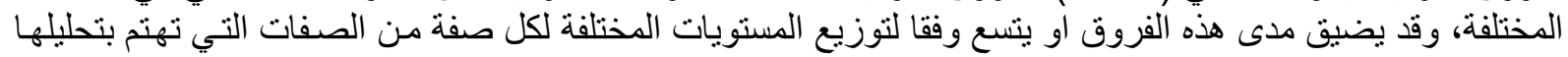

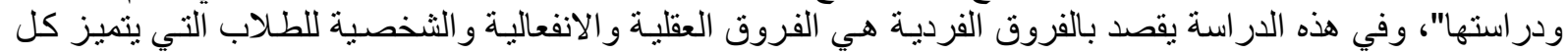

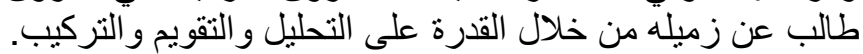

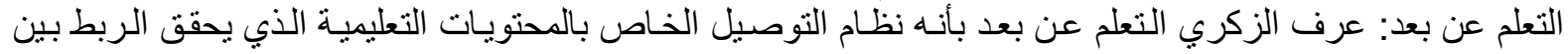

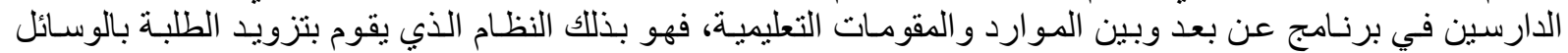

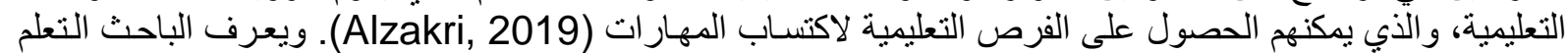

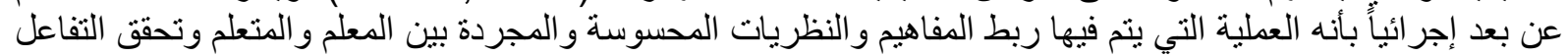

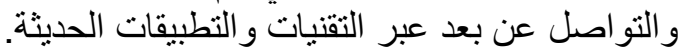

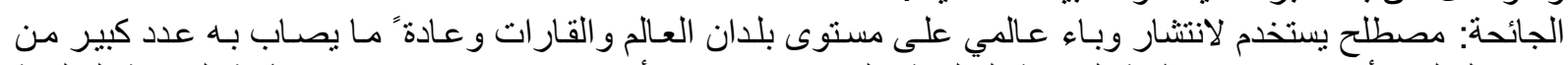

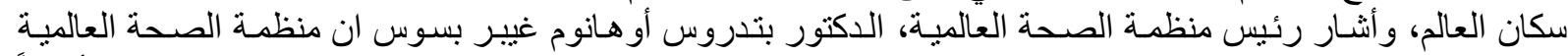

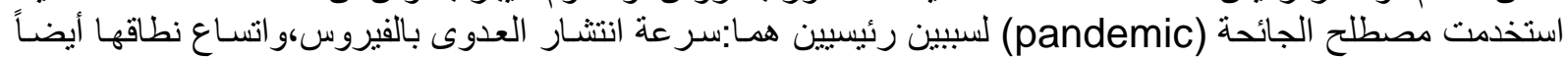

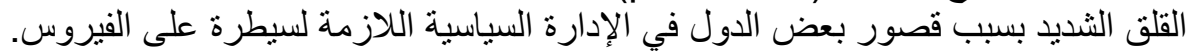

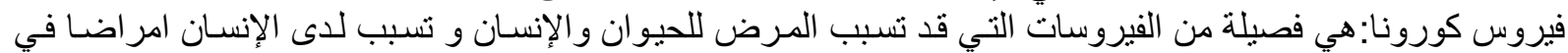

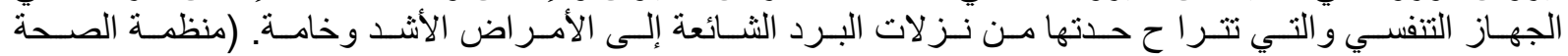

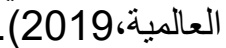

الطريقة والإجراءات

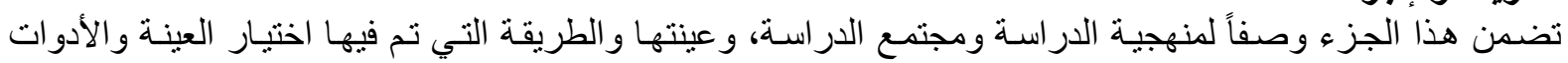

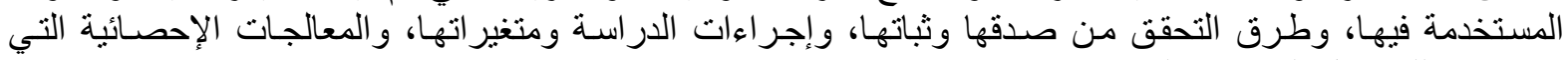
استخدمت للوصول إلى نتائج الدراسة التحن. 


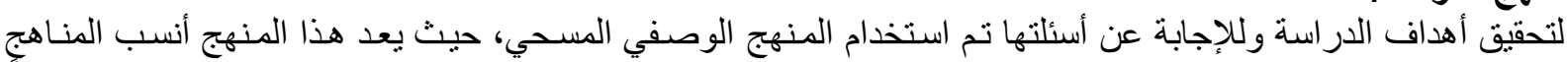

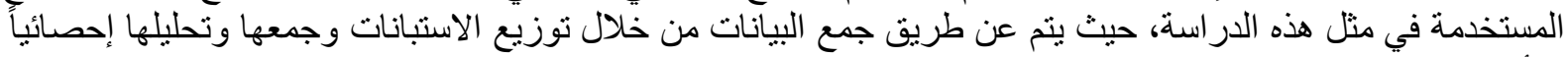
بالأساليب المناسبة.

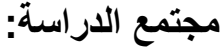

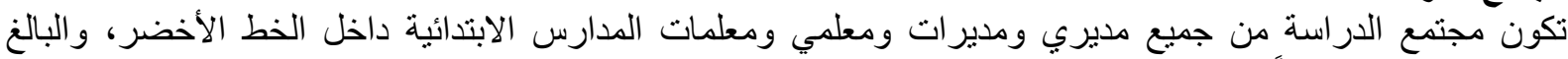
عددهم (6550) معلماً ومعلمة، على حسب منب احصائيات وز ارة التربية و والتعليم لعام (2021).

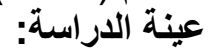
تم تطبيق أداة الدراسة على على عينة عشو ائية ميسرة ممثلة لمجتمع الدراسة من من المعلمين و المعلمات حيث بلغت نسبة

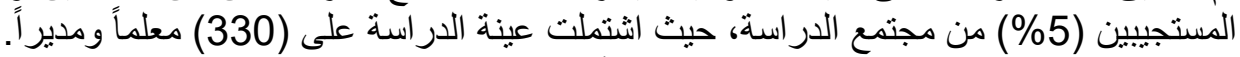

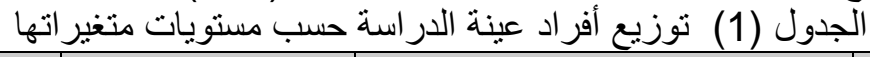

\begin{tabular}{|c|c|c|c|}
\hline النسبة المئوية\%\% & العدد & المستوى/الفئة & المتغير \\
\hline $47.9 \%$ & 158 & ذكر & \multirow{2}{*}{ الجنس } \\
\hline $52.1 \%$ & 172 & انتى & \\
\hline $20.0 \%$ & 66 & لقب اول & \multirow{4}{*}{ المؤهل العلمي } \\
\hline $26.7 \%$ & 88 & لقب ثاني & \\
\hline $24.2 \%$ & 80 & لقب ثالث & \\
\hline $29.1 \%$ & 96 & در اسات عليا & \\
\hline $35.5 \%$ & 117 & اقل من 10 سنوات & \multirow{2}{*}{ سنوات الخبرة } \\
\hline $64.5 \%$ & 213 & اكثر من 10 سنوات & \\
\hline $27.6 \%$ & 91 & علوم & \multirow{4}{*}{ التخصص } \\
\hline $37.3 \%$ & 123 & آداب & \\
\hline $15.8 \%$ & 52 & فنون & \\
\hline $19.4 \%$ & 64 & تكنولوجيا & \\
\hline
\end{tabular}

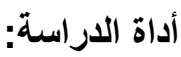

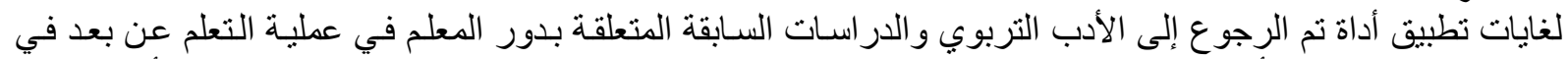

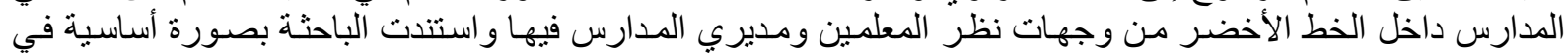

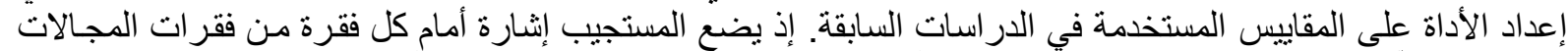

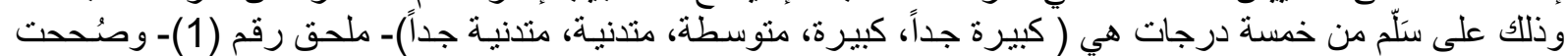

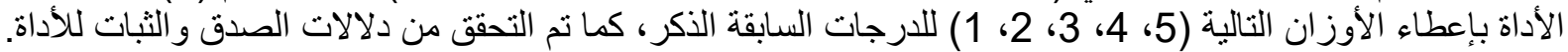
صدق أداة الدراسة الاستة تم تطبيق الاستبانة على عينة استطلاعية قوامها (30) معلماً من مجتمع الدر اسـة، وتم استبعادهم من عينـة الدر اسـة. وتم

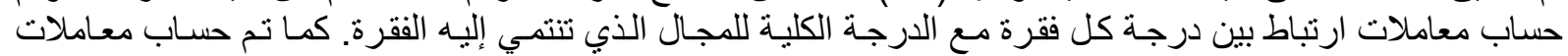

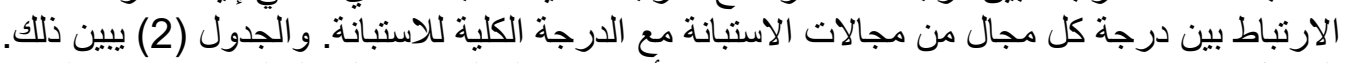

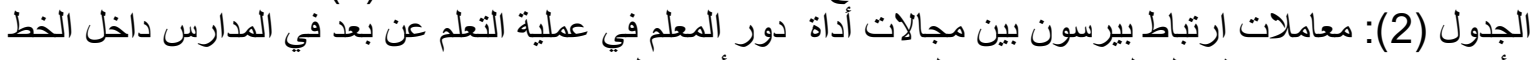

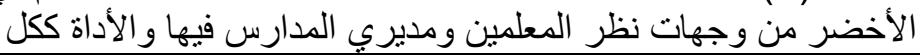

\begin{tabular}{|c|c|c|c|c|}
\hline الاداة الكلية & التقويم & التنفيذ & التخطيط & \\
\hline **.964 & **.930 & **.877 & 1 & التخطيط \\
\hline **.963 & **.916 & 1 & & التنفيذ \\
\hline **.979 & 1 & & & التقويم \\
\hline 1 & & & & الاداة الكلية \\
\hline
\end{tabular}




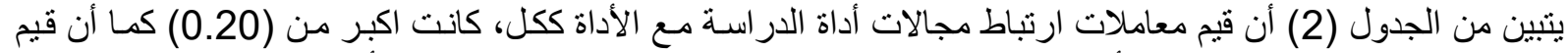

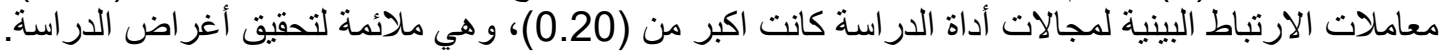

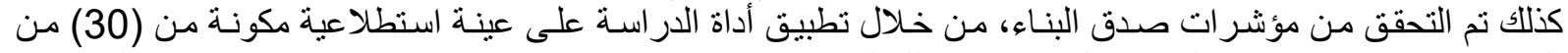

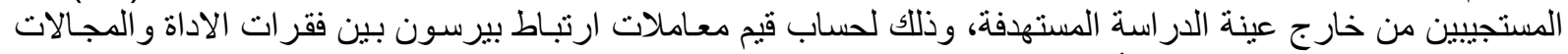

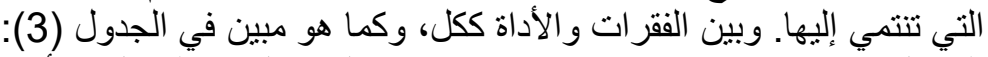

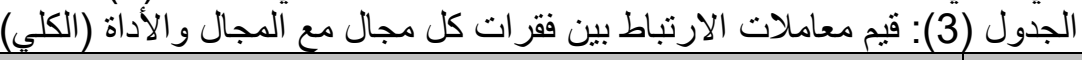

\begin{tabular}{|c|c|c|c|}
\hline \multicolumn{2}{|r|}{ 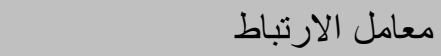 } & \multirow{2}{*}{ 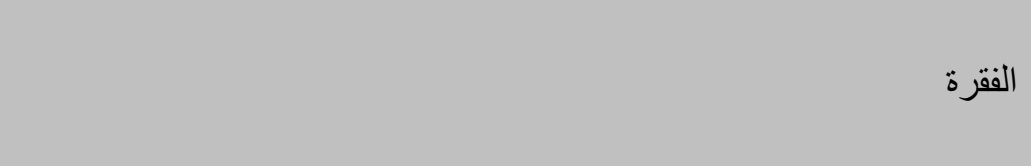 } & \multirow{2}{*}{ المجال } \\
\hline 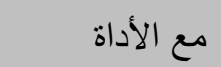 & مع المجال & & \\
\hline **.725 & **.796 & يحرص على تصميم خطة يومية و اضحة وشاملة وقابلة للتنفيذ لجميع الطلبة & \multirow{12}{*}{ التخطبط } \\
\hline **.724 & **.768 & يحرص على تصميم خطة ذات معنى & \\
\hline **.795 & **.823 & يعمل على بناء خطة فصلية شاملة لجميع المحتوى التعليمي الإلكتروني & \\
\hline **.757 & **.805 & ير اعي تنوع النتاجات التعليمية في الخطة اليومية & \\
\hline **.742 & **.796 & يقوم ببناء خطط تدخل للطلاب التحديات & \\
\hline **.772 & **.822 & ير اعي ملاءمة استر اتيجيات التدريس للنتاجات التعليمية & \\
\hline **.679 & **.699 & يقوم تنويع الأنشطة و الوسائل التعليمية التي تلائم حاجات الطلبة & \\
\hline **.745 & **.735 & ير اعي انسجام الخطط اليومية مع الخطة الفصلية & \\
\hline **.769 & **.764 & يوزع وقت الحصة على الأنشطة بشكل مناسب & \\
\hline **.805 & **.832 & يخطط لانشطة مجتمعية من خلال المنصـات الرقمية المتعددة & \\
\hline **.797 & **.795 & يتم إثر الك الأهل في العطلية التعليمية التعلمية من خلال وضع الخطط المناسبة & \\
\hline **.825 & ${ }^{* *} .842$ & يحرص على تصميم خطة فصلية واضحة وشاملة وقابلة للتنفيذ & \\
\hline **.851 & **.873 & يقوم بتجريب أفكار جديدة تركز على السيرورة و التعلم من عدة اتجاهات & \multirow{7}{*}{ 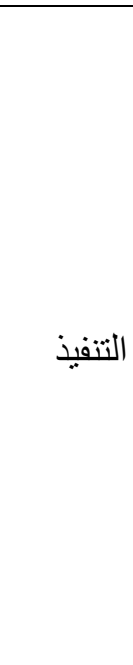 } \\
\hline **.758 & **.820 & يصدم الدروس لتحقيق النمو المتكامل لشخصية الطالب & \\
\hline **.829 & **.843 & يختار بعناية استر اتيجيات تعليم تراعي الفروق الفردية بين الطلبة & \\
\hline **.778 & **.810 & يستخدم نتائج التقويم لتصميم عملية التعلم & \\
\hline **.770 & **.833 & ويو تحصر مهاماً تشجع الطلبة على الحوار والنقاش و الاستفسار لتعميق) فههمج & \\
\hline **.837 & **.856 & يوفر مهاماً مختلفة تكسب مهار ات التفكير بمستوياتها المختلفة & \\
\hline **.823 & **.861 & يستثمر جميع فضاءات التكنولوجيا في دعم عمليتي التعليم و التعلم & \\
\hline
\end{tabular}


THE ROLE OF THE TEACHER IN THE DISTANCE LEARNING PROCESS IN

LIGHT OF THE CORONA PANDEMIC AND ITS RELATIONSHIP TO TAKING

INTO ACCOUNT INDIVIDUAL DIFFERENCES AMONG STUDENTS IN ARAB

PRIMARY SCHOOLS

\begin{tabular}{|c|c|c|c|}
\hline **.818 & ** .821 & يتم استخدام استر اتيجيات تدريسية متتو عة & \\
\hline **.881 & **.885 & يركز على التتويع في طرق التدريس داخل الغرفة الصفية وخارجها & \\
\hline **.768 & **.819 & ينم تشجيع العمل التعاوني من خلال الوسائل الرقمية & \\
\hline **.808 & **.856 & يقدم بر امج علاجيه للطلاب ذوي التحديات & \\
\hline **.823 & **.820 & تصاغ الاسئلة بلغة واضحة & \multirow{12}{*}{ 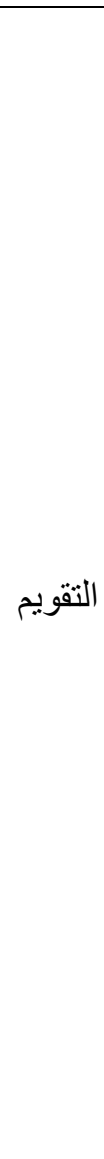 } \\
\hline **.716 & $*$ *.757 & تكون اسئلة التقويم شاملة للمحتوى التعليمي الإلكتروني & \\
\hline **.800 & **.841 & ينوع المعلم الاسئلة من مقالية وموضوعية & \\
\hline **.855 & **.894 & يعمل تغطية جميع الافكار و المفاهيم في المحتوى التعليمي & \\
\hline **.758 & **.808 & يربط الاسئلة بالاهداف العامة للمنهج & \\
\hline **.836 & ** .870 & ير اعي المجالات المعرفية للطلبة & \\
\hline **.792 & **.851 & تر اعي الاسئلة المجال المهاري للطلبة & \\
\hline **.937 & **.904 & يكثف المعلم الخبرات السابقة للطالب & \\
\hline **.962 & **.918 & يدفع الطلبة للتجربة و التعلم الفعال & \\
\hline **.950 & **.914 & يعمل على مر اعاة المجالات المعرفية و الذهنية للطلبة & \\
\hline **.931 & **.982 & ير اعي المجالات الوجدانية و العاطفية للطلبة & \\
\hline **.962 & **.984 & يعمل على قياس قدرة الطلبة على حفظ وتذكر المعلومات من النصوص & \\
\hline
\end{tabular}

(0.05). (0.01). (0.01). (0.01).

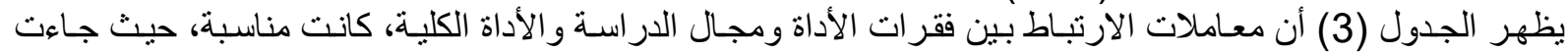

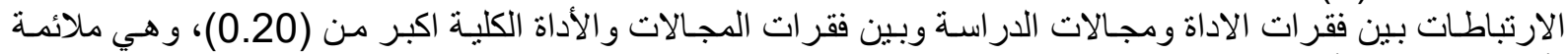

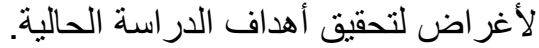

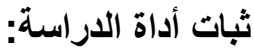

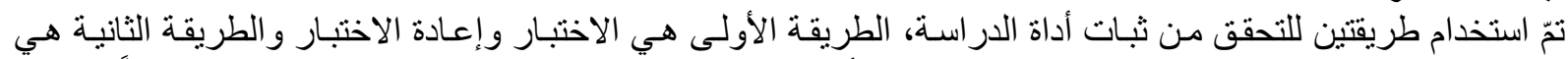

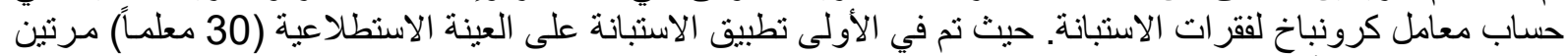

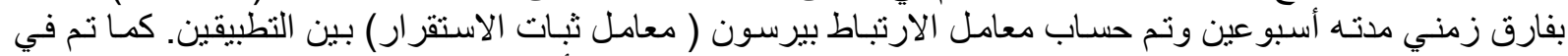

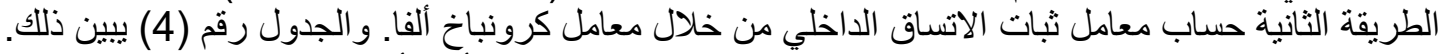

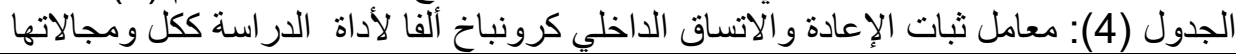




\begin{tabular}{|c|c|c|}
\hline 0.921 & 0.891 & التخطيط \\
\hline 0.901 & 0.912 & التتفيذ \\
\hline 0.897 & 0.871 & التقويم \\
\hline 0.936 & 0.941 & الأداة الكلية \\
\hline
\end{tabular}

أظهرت النتائج في الجدول (4) أن معامل ارتباط بيرسون بين درجات المفحوصين على الأداة في مرنتي التطبيق بلغ

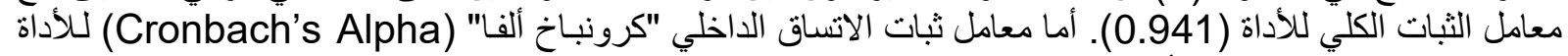

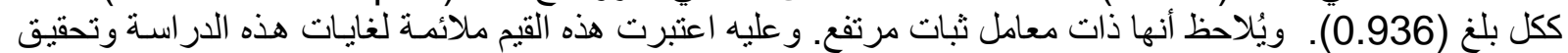
غرضها و الوثوق بنتائجها.

تصحيح أداة الاراسة الأنة

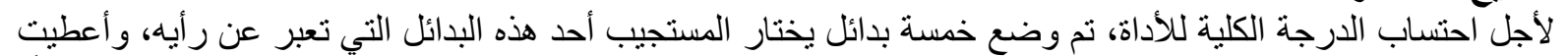

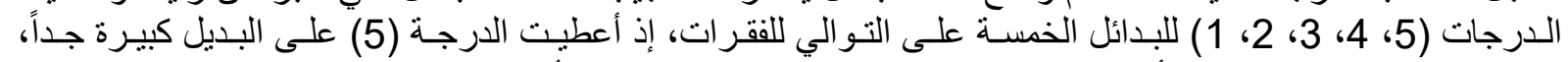

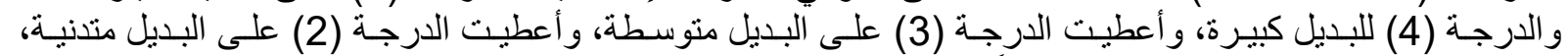

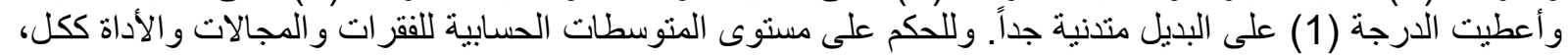

اعتمد المعيار الإحصائي باستخدام المعادلة الآتية: الإنية

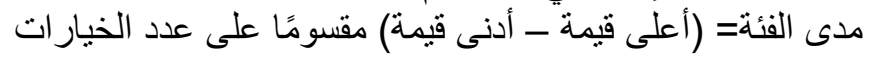

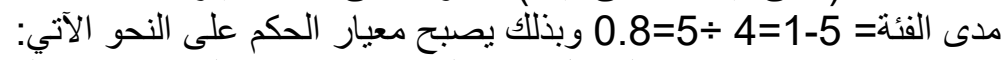
الجدول (5): المعبار الإحصائي لتحديد درجئ النجو الآنتوسطات الحسابية

\begin{tabular}{|c|c|}
\hline الدرجة & المتوسط الحسابي \\
\hline متدنية جداً & من 1.00 أقل من 1.80 \\
\hline متدنية & 1.80 أقل من 2.60 \\
\hline منوسطة & 2.60 أقل من 3.40 \\
\hline كبيرة & من 3.40 أقل من 4.20 \\
\hline كبيرة جداً & من 4.20 - 5.00 \\
\hline
\end{tabular}

من أجل الاجابة عن أسئلة الدراسة بصورة صحيحة قامت الباحثة باتباع الإجر اءات الآتية:

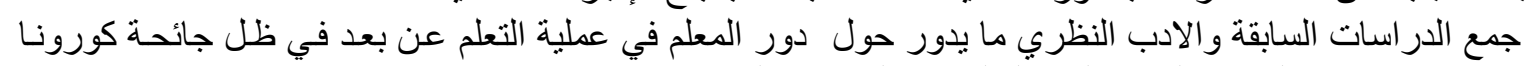

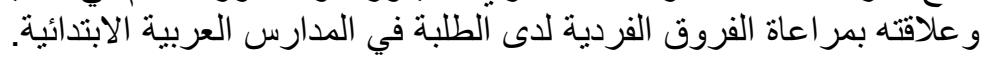

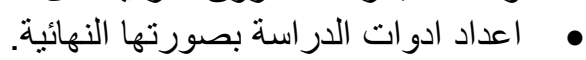

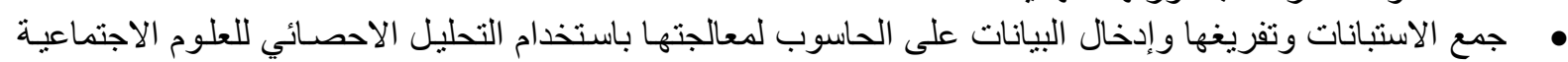
(SPSS)

أساليب المعالجة الإحصائية:

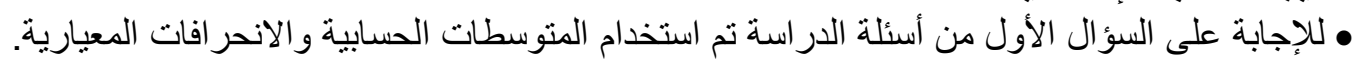

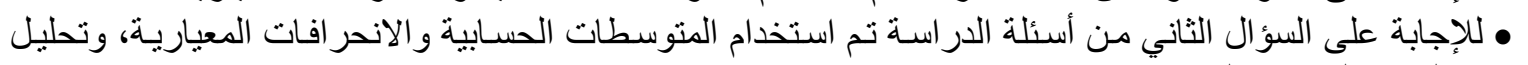

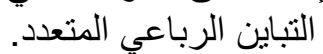
عرض النتائج

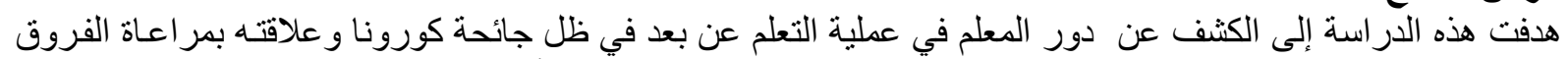

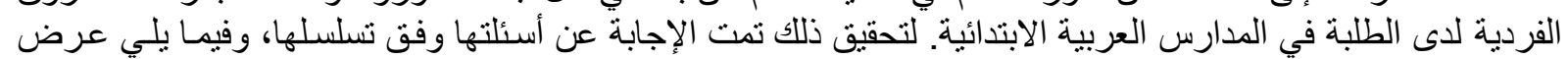

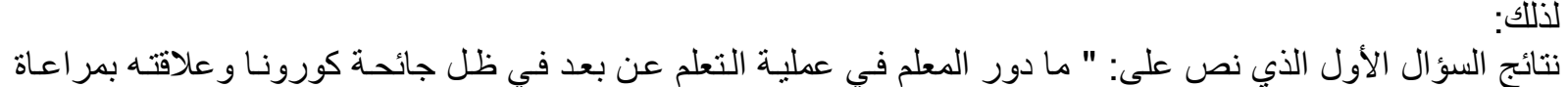

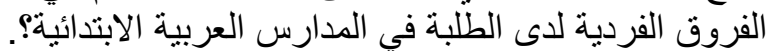

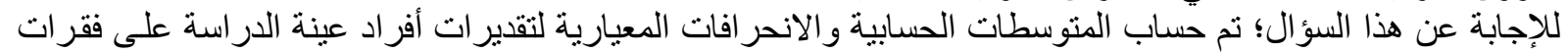

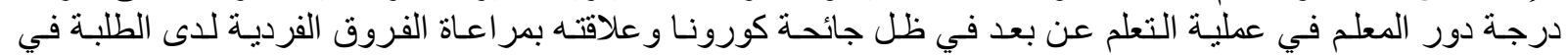

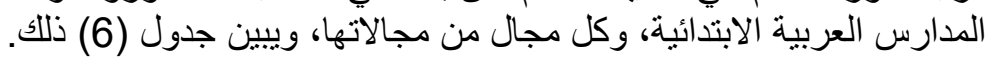

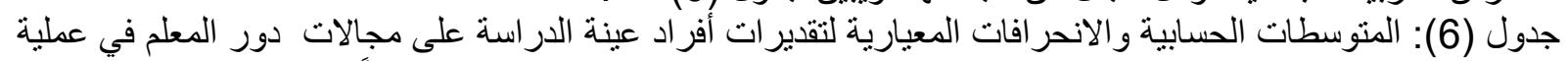

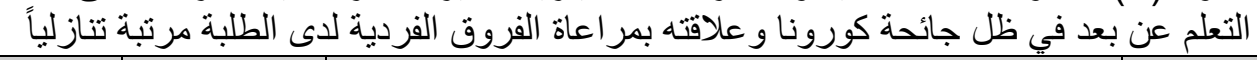

\begin{tabular}{|c|c|c|c|c|c|}
\hline الدرجة & الرتبة & الانحياري & الصسابي * المتوسط & المجال & رقمجال \\
\hline كبيرة & 1 & .871 & 3.81 & التخطيط & 1 \\
\hline
\end{tabular}




\section{THE ROLE OF THE TEACHER IN THE DISTANCE LEARNING PROCESS IN LIGHT OF THE CORONA PANDEMIC AND ITS RELATIONSHIP TO TAKING INTO ACCOUNT INDIVIDUAL DIFFERENCES AMONG STUDENTS IN ARAB PRIMARY SCHOOLS}

\begin{tabular}{|c|c|c|c|c|c|}
\hline كبيرة & 2 & .920 & 3.76 & التقويم & 3 \\
\hline كبيرة & 3 & .938 & 3.73 & التنفيذ & 2 \\
\hline كبيرة & & .881 & 3.77 & الاداة الكلية & 4 \\
\hline
\end{tabular}

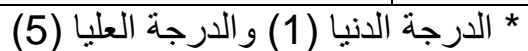

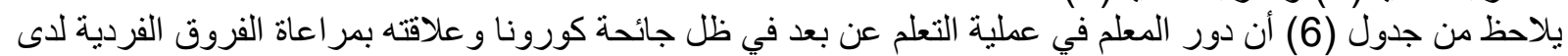

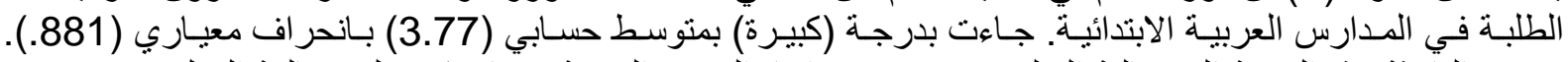

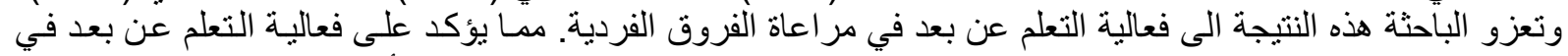

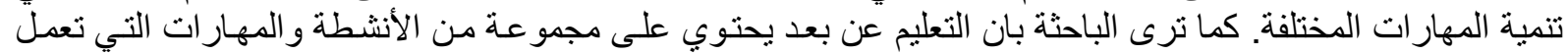

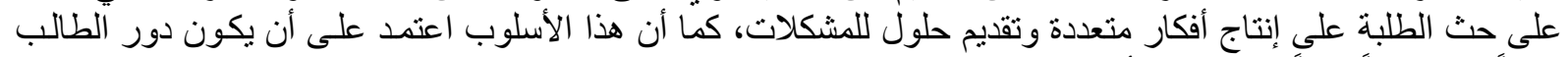

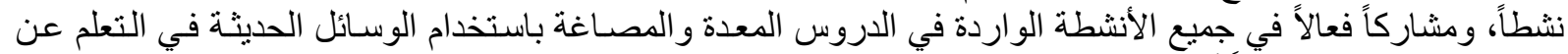

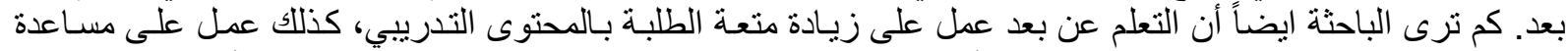

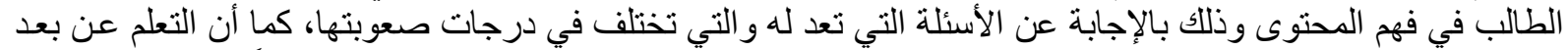

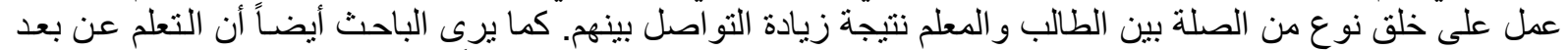

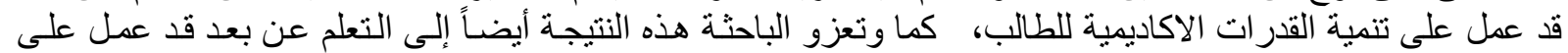

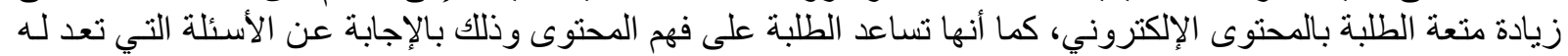

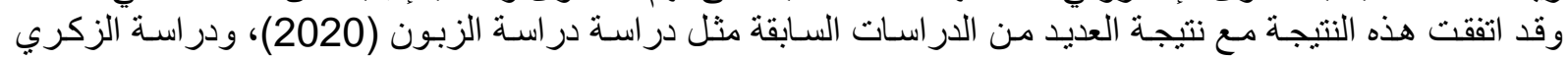

(2019)، ودر اسة الغامدي (2019).

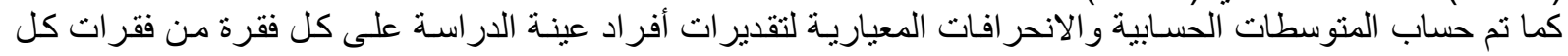

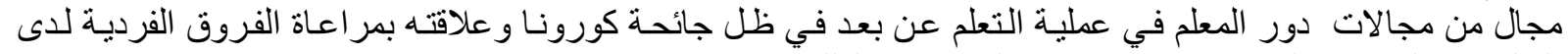

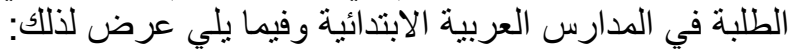

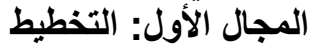

الجدول (7): المنوسطات الحسابية والانحر افات المعيارية لتقدير ات أفر اد عينة الدراسة على فقرات المجال (التخطيط)،

مرتبة تنازلياً وفق المتوسطات الحسابية

\begin{tabular}{|c|c|c|c|c|c|}
\hline 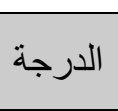 & 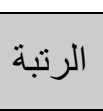 & 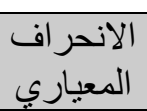 & المستوسط & 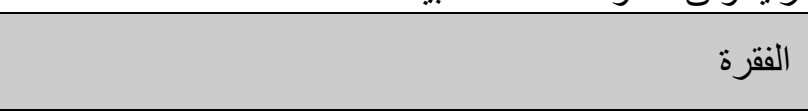 & 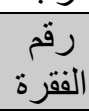 \\
\hline كبيرة & 1 & 1.093 & 3.98 & الطلبة تنويع الأنشطة والوسائل التعليمية التي تلائم حاجات & 7 \\
\hline 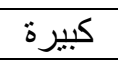 & 2 & .995 & 3.92 & يوزع وقت الحصة على الأنشطة بشكل مناسب & 9 \\
\hline كبيرة & 3 & 1.034 & 3.90 & للتنفرصذ لجميع الطلبة تصيم خطة يومية واضحة وشاملة وقابلة & 1 \\
\hline كبيرة & 4 & 1.087 & 3.90 & ير اعي تنوع النتاجات التعليمية في الخطة اليومية & 4 \\
\hline كبيرة & 5 & 1.075 & 3.83 & يقوم ببناء خطط تدخل للطلاب التحديات & 5 \\
\hline كبيرة & 6 & 1.049 & 3.80 & يخطط لانشطة مجتمعية من خلال المنصات الرقمية المتعددة & 10 \\
\hline كبيرة & 7 & 1.085 & 3.79 & الإلكتروني على بناء خطة فصلية شاملة لجميع المحتوى التعليمي & 3 \\
\hline كبيرة & 8 & 1.226 & 3.78 & ير اعي انسجام الخطط اليومية مع الخطة الفصلية & 8 \\
\hline كبيرة & 9 & 1.153 & 3.72 & ير اعي ملاءمة استر اتيجيات التدريس للنتاجات التعليمية & 6 \\
\hline كبيرة & 10 & 1.122 & 3.71 & يحرص على تصميم خطة ذات معنى & 2 \\
\hline كبيرة & 11 & 1.151 & 3.78 & يتم إثر الك الأهل في العملية التعليمية التعلمية من خلال & 11 \\
\hline 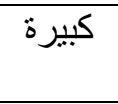 & 12 & 1.166 & 3.65 & للتنفريذ على تصميم خطة فصلية و اضحة وشاملة وقابلة & 12 \\
\hline كبيرة & & .871 & 3.81 & التخطبط & \\
\hline
\end{tabular}

* الدرجة الدنيا (1) و الدرجة العليا (5) م) 


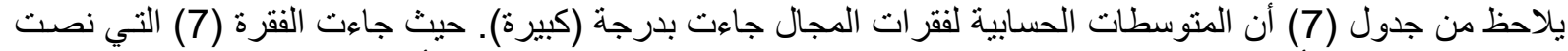

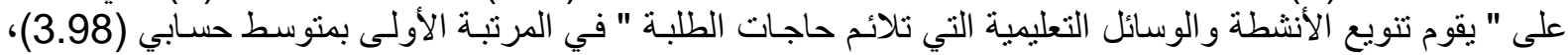

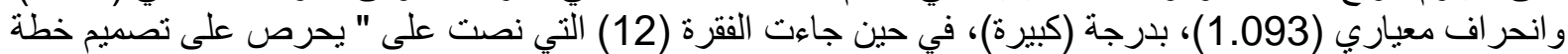

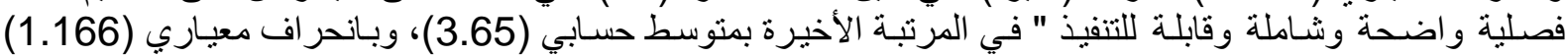

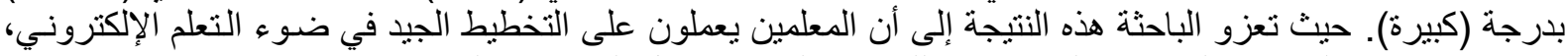

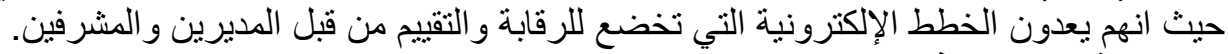

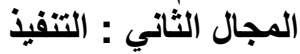
الجدول (8): المتوسطات الحسابية والانحر افات المعيارية لتقدير ات أفراد عينة الدر اسة على فقرات المجال (التنفيذ)، مرتبة تنازلياً وفق المنوسطات الحسابية

\begin{tabular}{|c|c|c|c|c|c|}
\hline 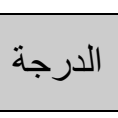 & 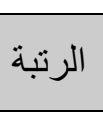 & 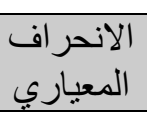 & المنتوسط & 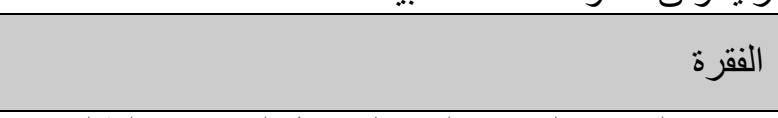 & 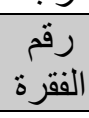 \\
\hline كبيرة & 1 & 1.040 & 3.91 & يصمم الدروس لتحقيق النمو المتكامل لشخصية الطالب & 2 \\
\hline 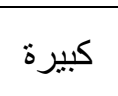 & 2 & 1.076 & 3.85 & الطلتبة بعناية استر اتيجيات تعليم تر اعي الفروق الفردية بين & 3 \\
\hline كبيرة & 3 & 1.054 & 3.84 & لتعميق) فهمهر وتحمع الطلبة على الحوار و النقاش والاستفسار & 5 \\
\hline كبيرة & 4 & 1.098 & 3.81 & يتم تشجيع العمل التعاوني من خلال الوسائل الرقمية & 10 \\
\hline 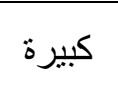 & 5 & 1.027 & 3.77 & عدة اتجاهريب أفكار جديدة تركز على السيرورة والتعلم من & 1 \\
\hline كبيرة & 6 & 1.060 & 3.75 & يقدم بر امج علاجيه للطلاب ذوي التحديات & 11 \\
\hline 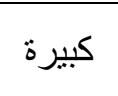 & 7 & 1.130 & 3.74 & ورالتعلمر جميع فضاءات التكنولوجيا في دعم عمليتي التعليم & 7 \\
\hline كبيرة & 8 & 1.117 & 3.64 & اليوفتلفة مهاماً مختلفة تكسب مهار ات التفكير بمستوياتها & 6 \\
\hline كبيرة & 9 & 1.156 & 3.64 & وخركز على التنويع في طرق التدريس داخل الغرفة الصفية & 9 \\
\hline 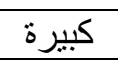 & 10 & 1.207 & 3.63 & يستخدم نتائج التقويم لتصميم عملية التعلم & 4 \\
\hline كبيرة & 11 & 1.279 & 3.42 & يتم استخدام استر اتيجيات تدريسية متنو عة & 8 \\
\hline كبيرة & 12 & .938 & 3.73 & التنفيذ & 12 \\
\hline
\end{tabular}

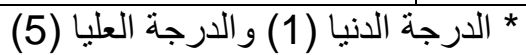

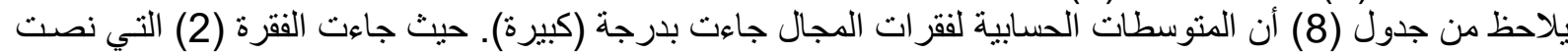

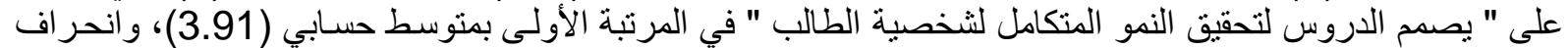

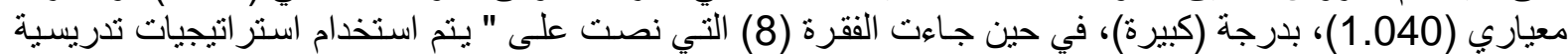

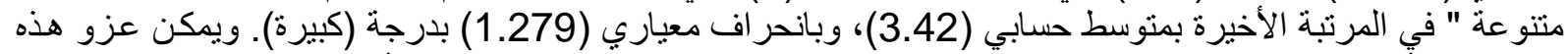

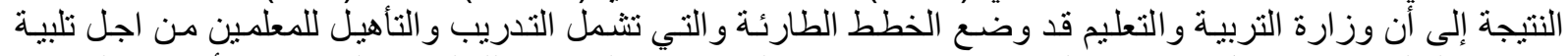

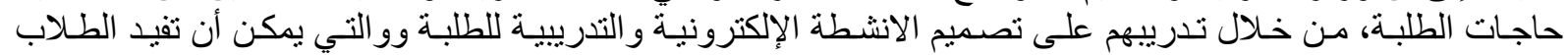

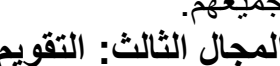

الجدول (9): المتوسطات الحسابية والانحر افات المعيارية لتقدير ات أفراد ادئ عينة الدراسة على فقرات المجال (التقويم)، مرتبة تنازلياً وفق المتوسطات الحسابية

\begin{tabular}{|c|c|c|c|c|c|}
\hline 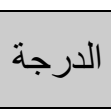 & 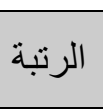 & الالانحرياري & الحسابي * المتوسط & الفقرة & الفقرة \\
\hline كبيرة & 1 & 1.036 & 3.99 & تكون اسئلة التقويم شاملة للمحتوى التعليمي الإلكتروني & 2 \\
\hline كبيرة & 2 & .879 & 3.83 & يكثف المعلم الخبرات السابقة للطالب & 8 \\
\hline كبيرة & 3 & 1.148 & 3.82 & ينوع المعلم الاسئلة من مقالية وموضو عية & 3 \\
\hline كبيرة & 4 & .907 & 3.79 & يدفع الطلبة للتجربة و التعلم الفعال & 9 \\
\hline كبيرة & 5 & .973 & 3.78 & ير اعي المجالات الوجدانية و العاطفية للطلبة & 11 \\
\hline كبيرة & 6 & .882 & 3.77 & يعمل على قياس قدرة الطلبة على حفظ وتذكر المعلومات من & 12 \\
\hline
\end{tabular}




\begin{tabular}{|c|c|c|c|c|c|}
\hline & & & & النصوص & \\
\hline كبيرة & 7 & 1.121 & 3.76 & تر اعي الاسئلة المجال المهاري للطلبة & 7 \\
\hline كبيرة & 8 & 1.153 & 3.74 & يربط الاسئلة بالاهداف العامة للمنهج & 5 \\
\hline كبيرة & 9 & 1.191 & 3.70 & يعمل تغطية جميع الافكار و المفاهيم في المحتوى التعليمي & 4 \\
\hline كبيرة & 10 & .975 & 3.68 & يعمل على مر اعاة المجالات المعرفية والذهنية للطلبة & 10 \\
\hline كبيرة & 11 & 1.188 & 3.67 & ير اعي المجالات المعرفية للطلبة & 6 \\
\hline كبيرة & 12 & 1.177 & 3.59 & تصاغ الاسئلة بلغة و اضحة & 1 \\
\hline كبيرة & & .920 & 3.76 & التقويم & \\
\hline
\end{tabular}

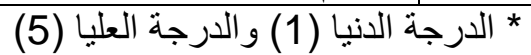
يلاحظ من جدول (9) أن المنوسطات الحسابية لفقر ات المجات المجال جاءت بدرجة (كبيرة). حيث جاءت الفقرة (2) التي نصت

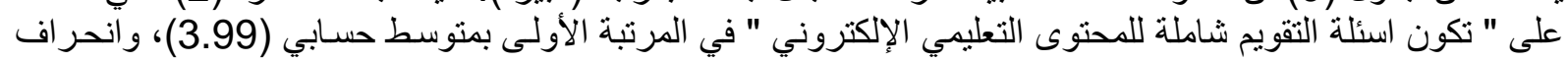

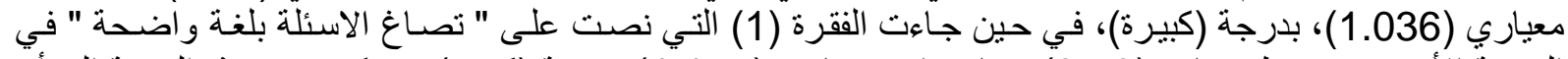

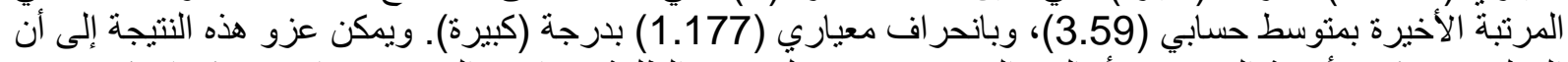

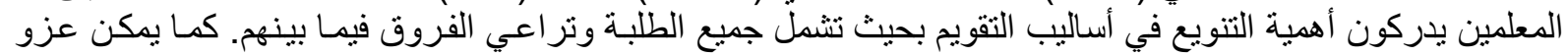
هذه النتيجة إلى الادر الك الكبير للمعلمين باستر اتيجيات التقويم و اشكاله وانو اع و اساليبه من اجل التحل تحقيق الاهداف التعليميـة

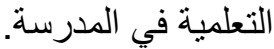
نتائج السؤال الثاني الذي نص على: " هل توجد فروق ذات دلالية إحصائية عند مستوى الدالالة الإحصـائية (a=0.05)

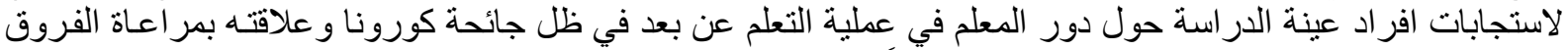

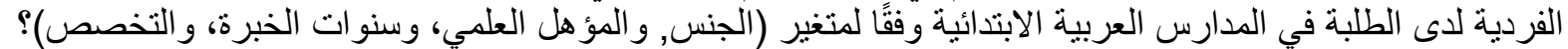

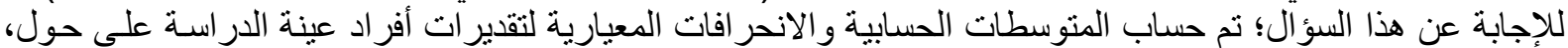

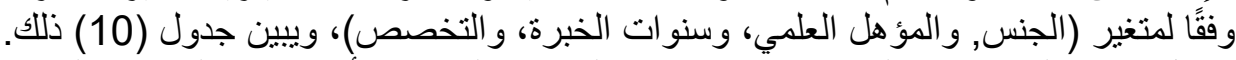

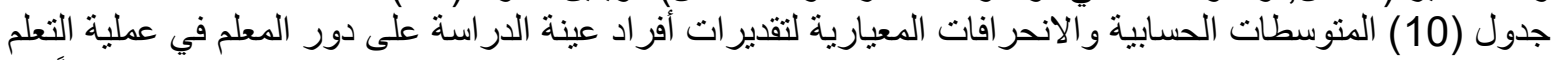

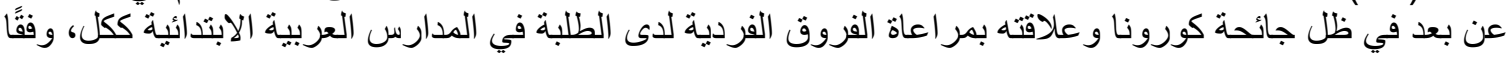

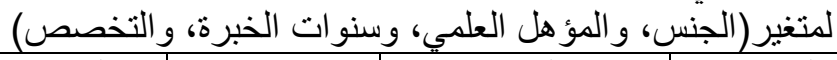

\begin{tabular}{|c|c|c|c|c|c|c|}
\hline الاداة الكلية & التقويم & التنفيذ & التخطيط & الإحصائي & الفئات & المتغير ات \\
\hline 3.85 & 3.85 & 3.81 & 3.88 & الحسابي & \multirow{3}{*}{ ذكر } & \multirow{9}{*}{ الجنس } \\
\hline 158 & 158 & 158 & 158 & العدد & & \\
\hline .888 & .913 & .927 & .878 & الالحياري اف & & \\
\hline 3.69 & 3.68 & 3.65 & 3.75 & الحستوسط & \multirow{3}{*}{ انثى } & \\
\hline 172 & 172 & 172 & 172 & العدد & & \\
\hline .872 & .921 & .945 & .863 & الانحريافي & & \\
\hline 3.77 & 3.76 & 3.73 & 3.81 & الحسابي & \multirow{3}{*}{ المجموع } & \\
\hline 330 & 330 & 330 & 330 & العدد & & \\
\hline .881 & .920 & .938 & .871 & الانحياري & & \\
\hline 3.75 & 3.72 & 3.76 & 3.78 & الحستوسي & \multirow{3}{*}{ لقب اول } & \multirow{3}{*}{ العؤ هل } \\
\hline 66 & 66 & 66 & 66 & العدد & & \\
\hline .936 & .996 & .941 & .939 & الانحر اف & & \\
\hline
\end{tabular}




\begin{tabular}{|c|c|c|c|c|c|c|}
\hline & & & & المعباري & & \\
\hline 3.72 & 3.73 & 3.65 & 3.77 & الحسابي & \multirow{3}{*}{ لقب ثاني } & \\
\hline 88 & 88 & 88 & 88 & العدد & & \\
\hline .904 & .929 & 1.009 & .861 & الانحرياري & & \\
\hline 3.66 & 3.68 & 3.60 & 3.71 & الحسابي & \multirow{3}{*}{ لقب ثالث } & \\
\hline 80 & 80 & 80 & 80 & العدد & & \\
\hline .823 & .850 & .912 & .805 & الالحياري اف & & \\
\hline 3.91 & 3.89 & 3.87 & 3.97 & الحسابي & \multirow{3}{*}{ در اسات عليا } & \\
\hline 96 & 96 & 96 & 96 & العدد & & \\
\hline .865 & .914 & .883 & .878 & الالحياري اف & & \\
\hline 3.77 & 3.76 & 3.73 & 3.81 & الحسابي & \multirow{3}{*}{ المجموع } & \\
\hline 330 & 330 & 330 & 330 & العدد & & \\
\hline .881 & .920 & .938 & .871 & الالحعرافي & & \\
\hline 3.74 & 3.73 & 3.66 & 3.83 & الحستوسط & \multirow{3}{*}{ اقل من 10 سنوات } & \multirow{9}{*}{ سنو الخبرة } \\
\hline 117 & 117 & 117 & 117 & العدد & & \\
\hline .969 & .992 & 1.076 & .949 & الانحر اف & & \\
\hline 3.78 & 3.78 & 3.76 & 3.80 & الحسابي & \multirow{3}{*}{ سنر من 10} & \\
\hline 213 & 213 & 213 & 213 & العدد & & \\
\hline .832 & .880 & .854 & .827 & الإنحر افياري & & \\
\hline 3.77 & 3.76 & 3.73 & 3.81 & الحسابي & \multirow{3}{*}{ المجموع } & \\
\hline 330 & 330 & 330 & 330 & العدد & & \\
\hline .881 & .920 & .938 & .871 & الالحعرافي & & \\
\hline 3.68 & 3.69 & 3.64 & 3.70 & الحستوسط & \multirow{3}{*}{ 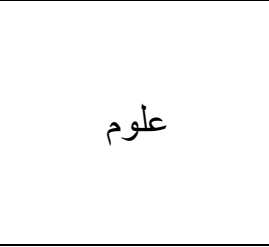 } & \multirow{7}{*}{ التخصص } \\
\hline 91 & 91 & 91 & 91 & العدد & & \\
\hline .797 & .853 & .845 & .804 & الانحرياري & & \\
\hline 3.81 & 3.77 & 3.77 & 3.88 & الحسابي & \multirow{3}{*}{ آداب } & \\
\hline 123 & 123 & 123 & 123 & العدد & & \\
\hline .913 & .955 & .941 & .898 & الانحياري اف & & \\
\hline 3.71 & 3.68 & 3.64 & 3.82 & الحستوسي & فنون & \\
\hline
\end{tabular}




\begin{tabular}{|c|c|c|c|c|c|}
\hline 52 & 52 & 52 & 52 & العدد & \\
\hline 1.034 & 1.078 & 1.176 & .952 & الالمعياري & \\
\hline 3.85 & 3.90 & 3.83 & 3.83 & الحسابي & \multirow{3}{*}{ تكنولوجيا } \\
\hline 64 & 64 & 64 & 64 & العدد & \\
\hline .802 & .801 & .844 & .846 & الالانحرياف & \\
\hline 3.77 & 3.76 & 3.73 & 3.81 & الحسنابي & \multirow{3}{*}{ المجموع } \\
\hline 330 & 330 & 330 & 330 & العدد " & \\
\hline .881 & .920 & .938 & .871 & الالانحريافي & \\
\hline
\end{tabular}

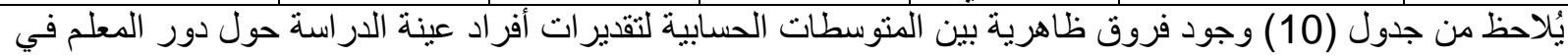

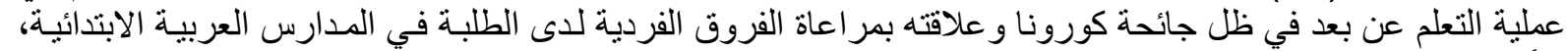

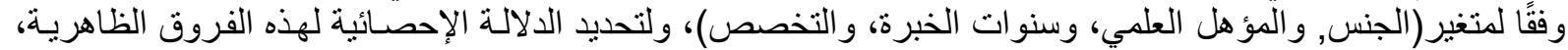

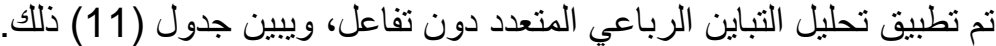

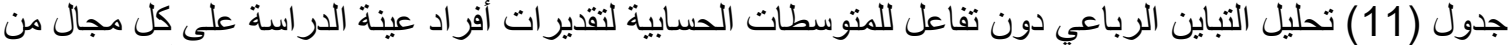

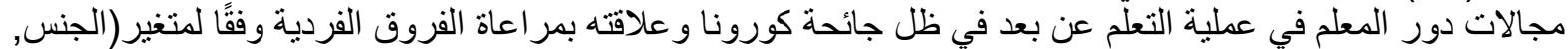

\begin{tabular}{|c|c|c|c|c|c|c|}
\hline الإحصلائية & قيمة ف & المربعات & الحرجية & المربعات & المجال & مصدر التباين \\
\hline .199 & 1.656 & 1.252 & 1 & 1.252 & التخطيط & \multirow{4}{*}{$\begin{array}{c}\text { الجنس } \\
\text { Hotelling's } \\
\text { Trace=.011 } \\
\text { Sig. }=.330\end{array}$} \\
\hline .127 & 2.347 & 2.062 & 1 & 2.062 & التنفيذ & \\
\hline .093 & 2.832 & 2.405 & 1 & 2.405 & التقويم & \\
\hline .122 & 2.410 & 1.873 & 1 & 1.873 & الاداة الكلية & \\
\hline .211 & 1.511 & 1.143 & 3 & 3.428 & التخطيط & \multirow{4}{*}{$\begin{array}{c}\text { المؤهل العلمي } \\
\text { Hotelling's } \\
\text { Trace=.030 } \\
\text { Sig.=.398 }\end{array}$} \\
\hline .222 & 1.473 & 1.294 & 3 & 3.883 & التنفيذ & \\
\hline .409 & .967 & .821 & 3 & 2.462 & التقويم & \\
\hline .260 & 1.343 & 1.044 & 3 & 3.132 & الاداة الكلية & \\
\hline .611 & .259 & .196 & 1 & .196 & التخطيط & \multirow{4}{*}{$\begin{array}{c}\text { سنوات الخبرة } \\
\text { Hotelling's } \\
\text { Trace=.020 } \\
\text { Sig.=.099 }\end{array}$} \\
\hline .482 & .495 & .435 & 1 & .435 & التنفيذ & \\
\hline .864 & .029 & .025 & 1 & .025 & التقويم & \\
\hline .887 & .020 & .016 & 1 & .016 & الاداة الكلية & \\
\hline .458 & .867 & .656 & 3 & 1.968 & التخطيط & \multirow{4}{*}{$\begin{array}{c}\text { Hotelling's } \\
\text { Hrace=.058 } \\
\text { Sig.=.032 }\end{array}$} \\
\hline .711 & .460 & .404 & 3 & 1.212 & التنفيذ & \\
\hline .760 & .390 & .331 & 3 & .994 & التقويم & \\
\hline .708 & .463 & .360 & 3 & 1.081 & الاداة الكلية & \\
\hline & & .756 & 321 & 242.719 & التخطيط & \multirow{4}{*}{ الخطأ } \\
\hline & & .879 & 321 & 282.068 & التنفيذ & \\
\hline & & .849 & 321 & 272.589 & التقويم & \\
\hline & & .777 & 321 & 249.488 & الاداة الكلية & \\
\hline & & & 330 & 5049.660 & التخطيط & المجموع \\
\hline
\end{tabular}




\begin{tabular}{|c|c|c|c|c|c|c|}
\hline الإحصائية & قيمة ف & متوسط المربعات & الحربة & المربعات & المجال & مصدر التباين \\
\hline & & & 330 & 4869.463 & التنفيذ & \\
\hline & & & 330 & 4946.224 & التقويم & \\
\hline & & & 330 & 4937.702 & الاداة الكلية & \\
\hline & & & 329 & 249.563 & التخطيط & \multirow{4}{*}{ المصحمح } \\
\hline & & & 329 & 289.660 & التنفيذ & \\
\hline & & & 329 & 278.476 & التقويم & \\
\hline & & & 329 & 255.590 & الاداة الكلية & \\
\hline
\end{tabular}

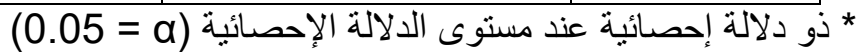

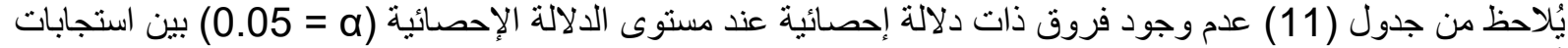

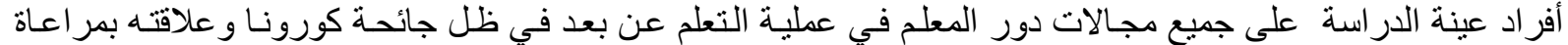

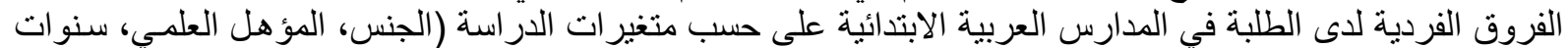

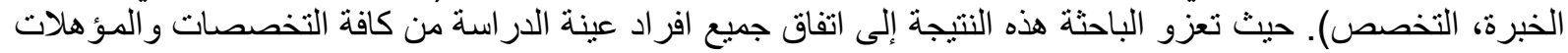

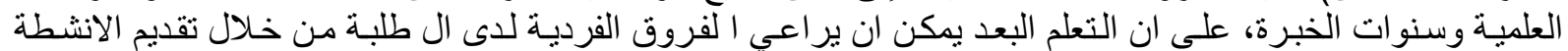

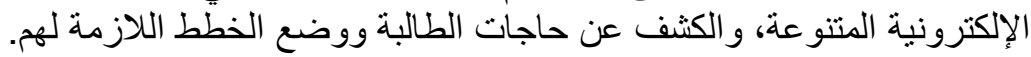

$$
\text { في ضوضيات: }
$$

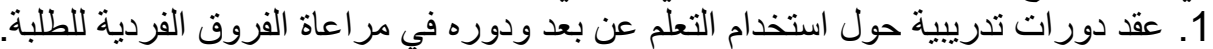

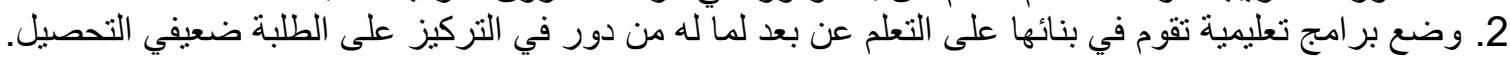

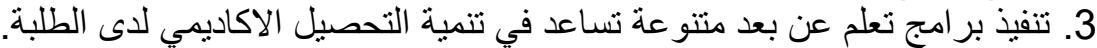

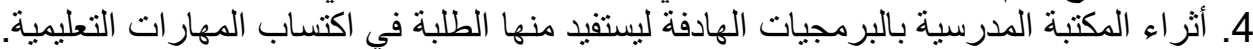

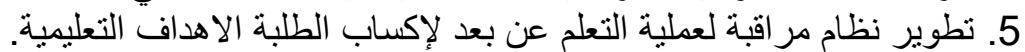
6. إجر اء در اسات أخرى مشابهة.

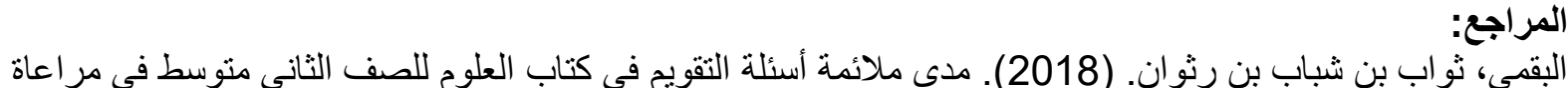

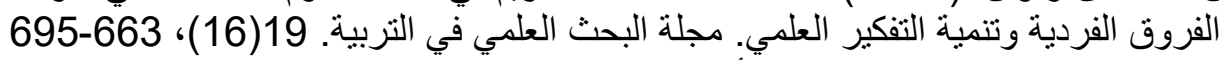

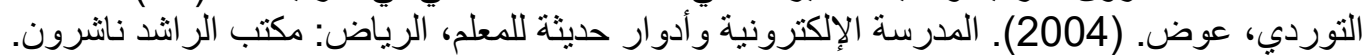

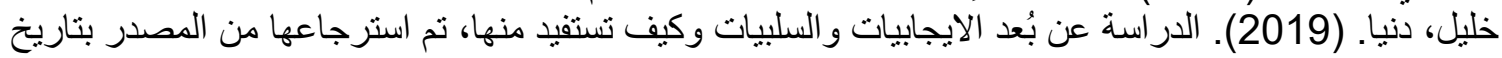
https://www.e7kky.com 2021/5/20

داودي، محمد. (2007). أثر الفروق الفردية في أساليب التعلم على الأداء في حل المشكلات: دراسة تجريبيـة على عينـة

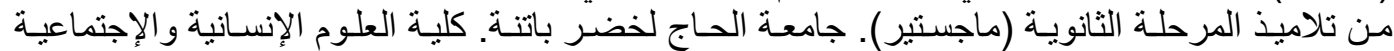

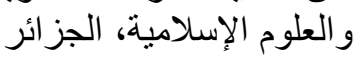

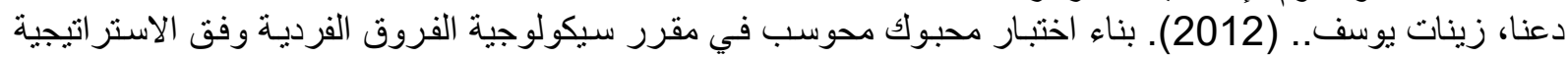
الهرمية (متعددة المستويات) في نظريـة الاستجابة للفقرة في جامعة طيبة. عالم التربيـة. 2012(2)، 153-

عامر، طارق. (2019). التعليم و التعليم الإلكترونيّ، (ط1)، عمان: دار اليازوري، الأردن.

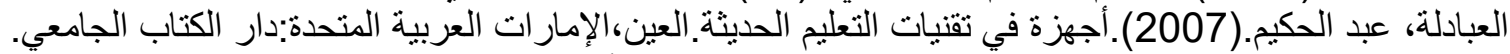

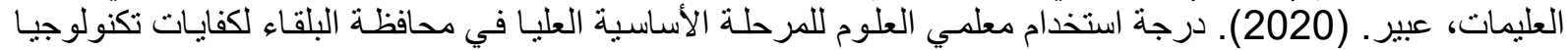

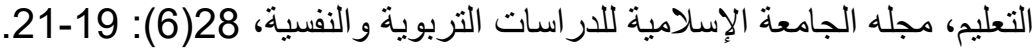

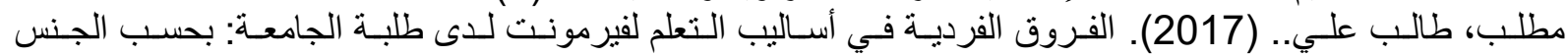

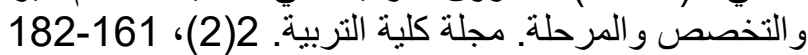

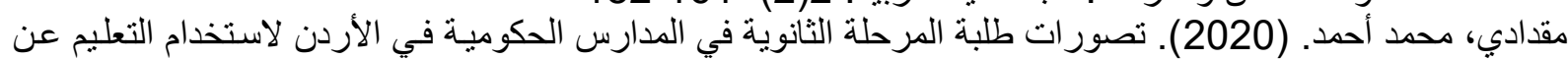

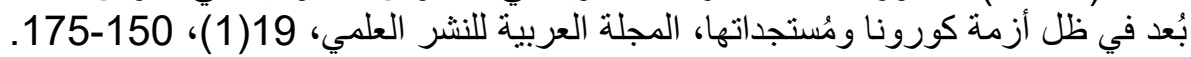

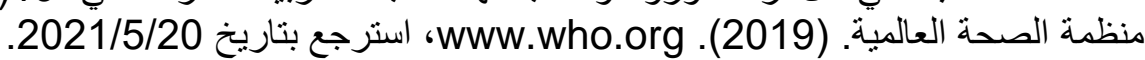

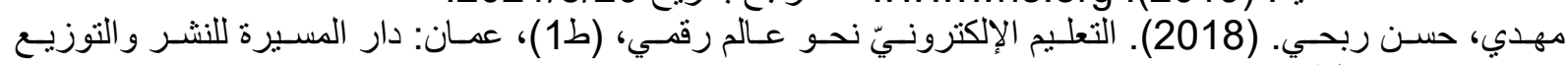

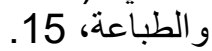


المراجع الاجنبية:

Alzboun, Khaled Odeh Muhammad. (2020). The effectiveness of distance learning compared to direct education in the achievement of first-grade students in the Arabic language subject in Jordan. Arab Journal of Specific Education. 4 (14), 201-220.

Salamah Waffa. (2020). The effectiveness of employing electronic mind maps in developing creative thinking skills in science research among ninth grade female students in Gaza governorates. Journal of the Islamic University of Educational and Psychological Studies. 28 (2), 79-106.

Abu Al Khail, Youssef Mufleh. (2020). The effect of an educational program based on the Web Quest on the development of creative thinking skills among students of the first grade of secondary school in computer research in Jordan. An-Najah University Journal for Research: Human Sciences. 34 (1), 159-186

Chou, C. \& Jeness R. (2014). Strategies and Challenges in I pad Initiative.10tH International Conference Mobile Learning University of St. Thomas Minnepolis,USA, 133-140.

June, S. (2012). E, elarning an evaluation of knowledge acquisition in training destination, Abstract International, 63, no. 068.

Madani, M. (2007). Distance Learning Goals Principles and Scientific Applications. Ed. 1. Amman, Jordan: Al-Maseerah Publishing.

Al-Zakri, Muhammad Ibrahim. (2019). The role of distance education in expanding access for deaf students to higher education: available programs and quality of services provided - the experience of the Arab Open University. Journal of Educational Sciences. 17 (1), 15-108.

Al-Ghamdi, Ahmed bin Abdullah Attia Koran. (2012). Evaluating the effectiveness of the distance learning system in some Saudi public universities and the students 'attitudes towards it, a PhD thesis. Umm Al Qura University. College of Education, Saudi Arabia

Attas, T. (2011). Developing Distance Education in Saudi Arabia Universities in the Light of Modern Universal Trends. Unpublished master thesis. Umm AlQura University, Saudi Arabia. 